\title{
Evaluating Credit Risk Based on Combined Model of Neural Network of Pattern Recognition and Ants' Colony Algorithm
}

Gholamreza Jandaghi ${ }^{1}$ Professor, Faculty of Management and Accounting, Farabi Campus University of Tehran, Qom, Iran.

Alireza Saranj ${ }^{2}$ Assistant Professor, Faculty of Management and Accounting, Farabi Campus University of Tehran, Qom, Iran (Author Corresponding).

Reza Rajaei ${ }^{3}$ Ph.D. of Financial Management, Faculty of Management and Accounting, Farabi Campus University of Tehran, Qom, Iran.

Ahmadreza Ghasemi ${ }^{4}$ Assistant Professor, Faculty of Management and Accounting, Farabi Campus University of Tehran, Qom, Iran.

Reza Tehrani ${ }^{5}$ Professor, Department of Financial Management., Faculty of Management, University of Tehran, Iran.

\begin{abstract}
A great amount of potential financial losses arise from borrowers' abstaining from refunding their debts calls and the development and improvement of credit risk measurement techniques in the financial literature in order to decrease such losses has transformed into an intevitable subject. The purpose of bankruptcy forecasting models is to estimate the probability of a company or a person's abstaining during a certain period of time. This research used the data gathered from a sample of 218 active companies in Tehran Stock Exchange Market as well as Over-The-Counter for the period between 1990 and 2016. Moreover, ants' colony algorithm was used to determine the most effective factors of credit risk and also pattern recognition neural network technique was applied to classify and evaluate the precision of bankruptcy forecasts. As a result, such ratios as profit before interests and taxes to total sale; total benefits of shareholders to debts; and current ratio, cash ratio and shareholders' benefits ratio to total assets are the most effective factors. Finally, the presented model which employs data belonging to one, two and three years before the intended year is able to forecast the credit condition of companies with higher precision as compared to the average precision of current models.
\end{abstract}

Keywords: Credit Risk, Bankruptcy Probability, Neural Network, Pattern Recognition Algorithm, Ants' Colony Aalgorithm.

\footnotetext{
1.jandaghi@ut.ac.ir

2. alisaranj@ut.ac.ir

3.r.rajaei@ut.ac.ir

4. ghasemiahmad@ut.ac.ir

5.rtehrani@ut.ac.ir
} 


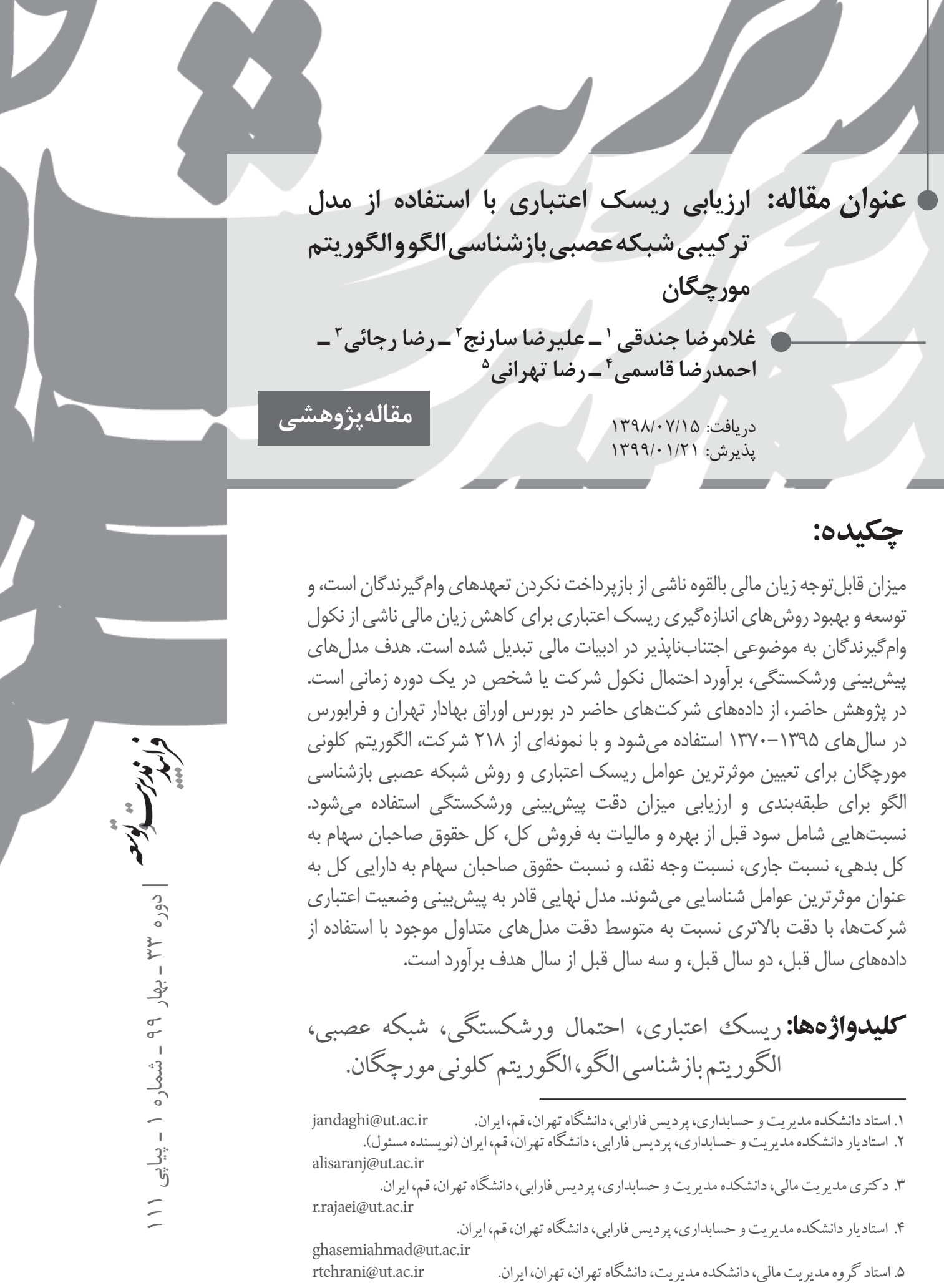

هـ استاد گروه مديريت مالى، دانشكده مديريت، دانشكاه تهران، تهران، ايران. 


\section{مقام}

ريسك اعتبارى مالى نشاندهنده ميزان زيان ناشى از قصور وامگيرنده است كه يا قادر به

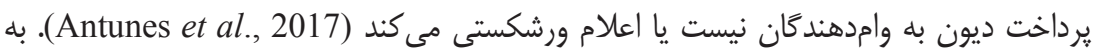

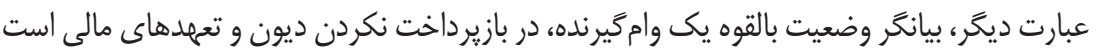
(Liu et al., 2019). هدف مديريت ريسك اعتبارى بيشينه كردن بازگشت اعتبارهاى دادهشده با پذيرش ميزان قابلقبولى از ريسك است (Fernandes \& Artes, 2016). ريسك اعتبارى، از بالهميتترين ريسكها در بانكها و موسسههاى مالى محسوب مىشود. براى موسسههاى مالى و بانكها بسيار مهرم است كه سيستمهاى هشداردهنده دقيقى در اختيار داشته باشند كه بتوانند ورشكستكى را ييش از وقوع ييشبينى كنند (Wang et al., 2017). بحران جهانى سال

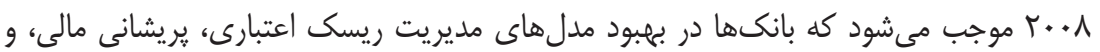
ورشكستخى تلاش بيشترى كنند (García et al., 2019). در توافق بازل' به منظور دستيابى

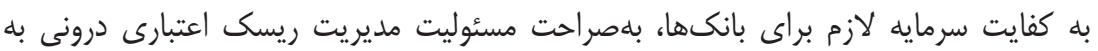
آنها محول مىشود. با مديريت اثربخش ريسك اعتبارى، بانكها علاوه بر حمايت از دوام

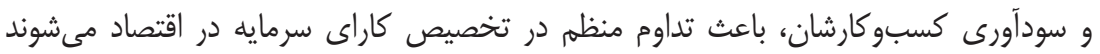

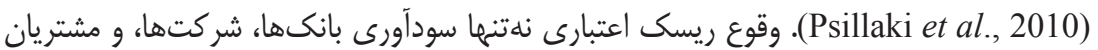
را خدشهدار مى رند، بلكه در مقياسى وسيعتر باعث قيديد آمدن خسران اقتصادى مىشود

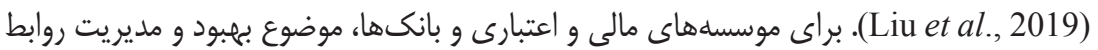

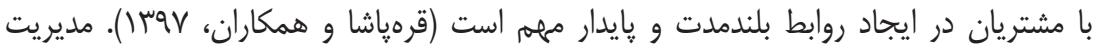
ريسك اعتبارى براى بانكها يك ضرورت است و حفظ كارايى در ريسك اعتبارى از اجزاى مهرم روش جامع مديريت ريسك است و جزو الزامهاى لازم براى موفقيت بلندمدت هر بانك محسوب

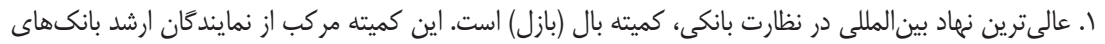

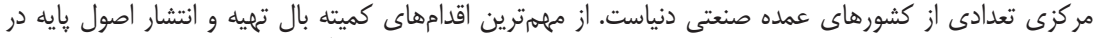

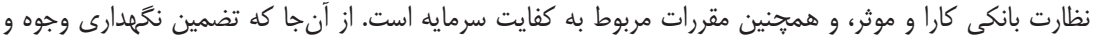

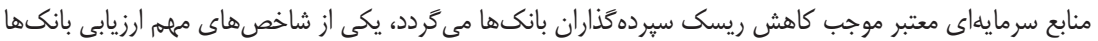

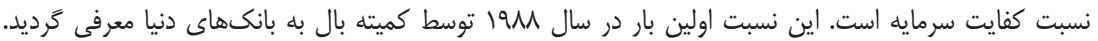

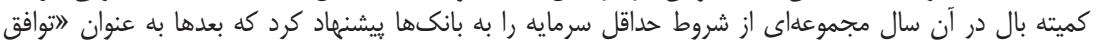
بازل " معروف شد. 
مىشود. كارايى با حفظ منابع سازمان رابطه مستقيم دارد و ايجاد نظام كارا و مصرف بهينه منابع

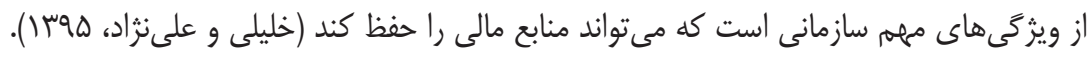

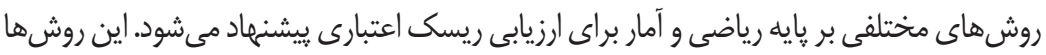
بيشتر به وسيله عوامل بيرونى، احتمال ورشكستكى را تخمين مىزنند (Fernandes \& Artes, 2016).

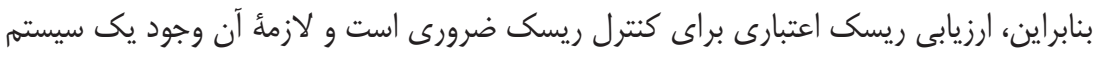

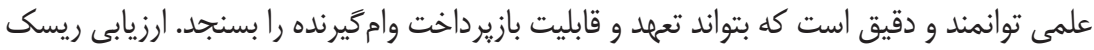

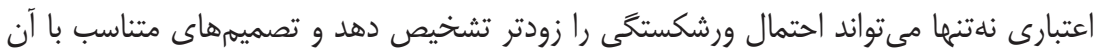

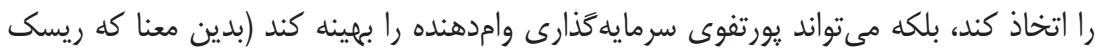

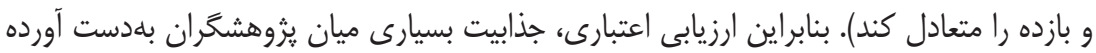
است (Djebali \& Zaghdoudi, 2020; Fanelli \& Maddalena, 2020). لازمه ارزيابى بنابع صحيح ريسك اعتبارى، وجود ابزارهاى تحليلى دقيق است كه قادر به ييشبينى ورشكستكى شركتها باشند و بتوانند با دقت بالا، شركتهاى مستعد ورشكستخى را از ميان ساير شركتها تشخيص دهند (Antunes et al., 2017). ورشكستى زمانى رخ مىدهد كه يك شركت يا شخص قادر به انجام تعهدهاى مالى (A)

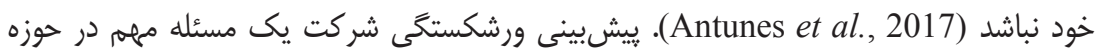
مديريت تصميم است و هدف اصلى آن ايجاد تمايز بين شركتهاى سالمى كه احتمال ورشكائنس

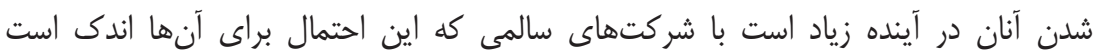

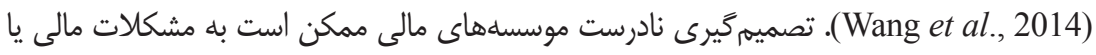

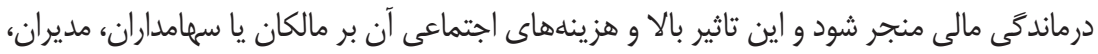

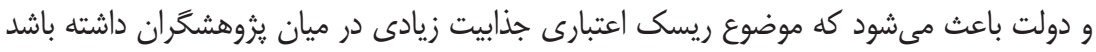
.Wang et al., 2014; Antunes et al., 2017; Liang et al., 2016; Jabeur, 2017) ورشكتخى شر كتها كه اغلب بلطور غيرمنتظره رخ مىدهد، نهتنها وجه مثبت شركتها را تحت

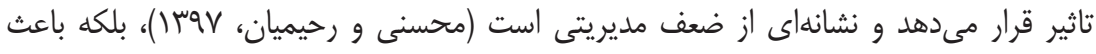

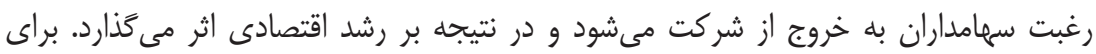
كاهش اثرهاى موارد اشارهشه، ييشينى ورشكستخى مهرم خواهل بود (Chou et al., 2017).

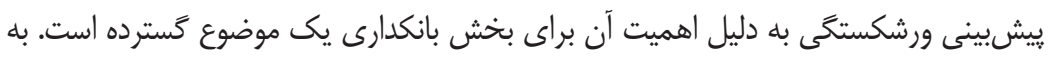

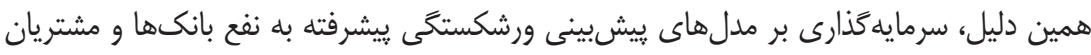

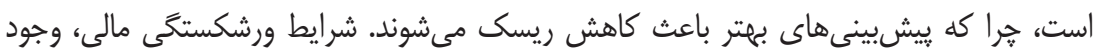


يك شركت را تحت تاثير قرار مىدهد و در صورتى كه شركت قادر به بازيرداخت بخشى از

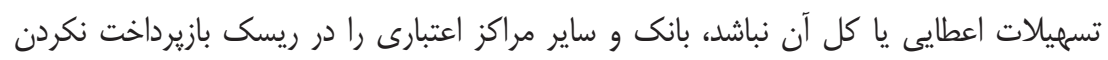

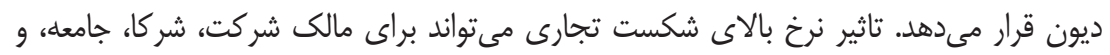

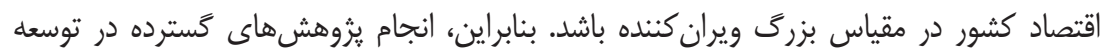
مدلهاى بيشبينى ورشكستى براى شركتها بدون شك مهرم است (Alaka et al., 2018).

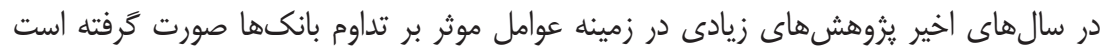
،(Djebali \& Zaghdoudi, 2020; Fanelli \& Maddalena, 2020; Veganzones \& Séverin, 2018) و بلهور خاص، ريسك اعتبارى به عنوان بزركترين ريسكى كه مىتواند در تداوم بانك تعيين كننده باشد، مورد توجه قرار كرفته است (Djebali \& Zaghdoudi, 2020).

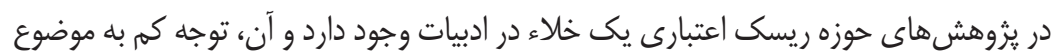
متغيرهاى ورودى به عنوان بخشى از عمليات ارائه مدل ريسك اعتبارى است. بسيارى از يزوهشها ترها

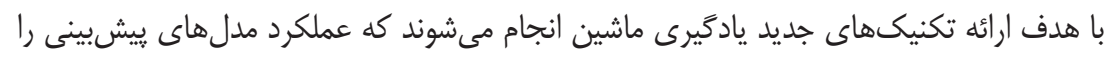

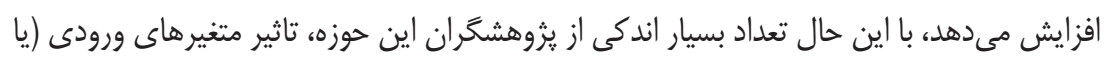
ويثگى ها) را بر عملكرد بيشيبنى بررسى مى كنند (Son et al., 2019; Volkov et al., 2017).

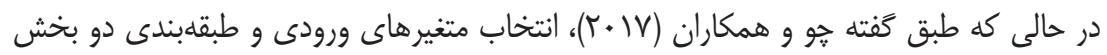

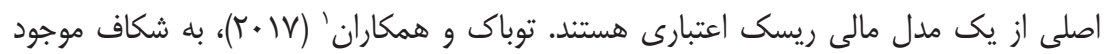

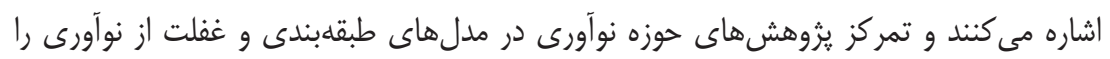

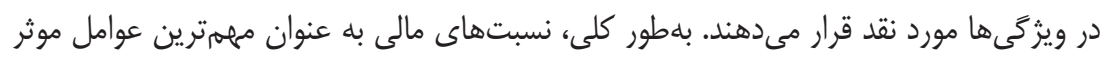

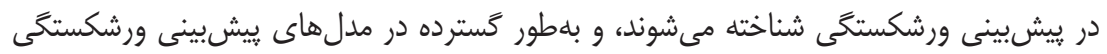
توسط يزوهشكران مورد استفاده قرار مى گيرند (Liang et al., 2016).

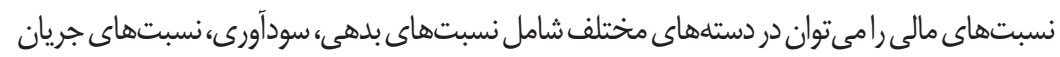

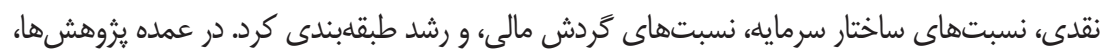

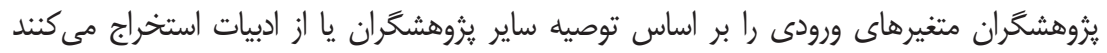
و)، (Barboza et al., 2017; Pompe \& Bilderbeek, 2005; Berg, 2007; Gepp \& Kumar, 2008)

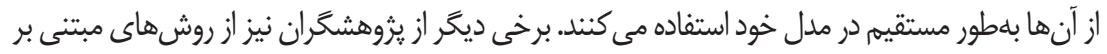
أمار و رياضى (Kim et al., 2016; Nam \& Jinn, 2000)، در انتخاب متغيرهاى ورودى مونى موثرتر استفاده

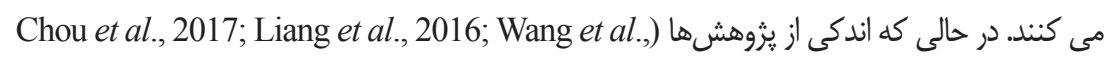
1. Tobback et al. 
2014; Chen et al., 2020 (20) با استفاده از تكنيكهاى هوش محاسباتى متغيرهاى ورودى مناسب را

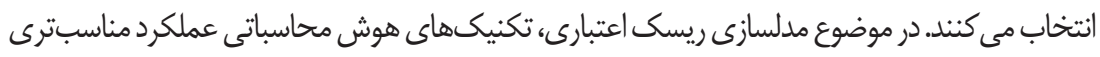

نسبت به تكنيكهاى مبتنى بر رياضى و آمار دارند (Son et al., 2019; Mai et al., 2019).

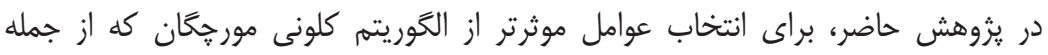

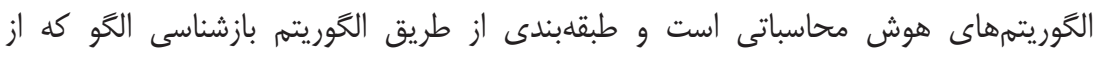
الكوريتمهاى شبكه عصبى است، استفاده مىشود. مدل نهايى با بكاركيرى همزمان دو روش

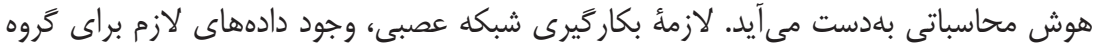

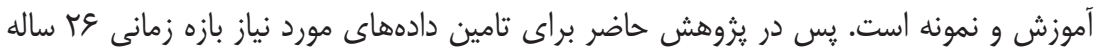

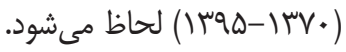

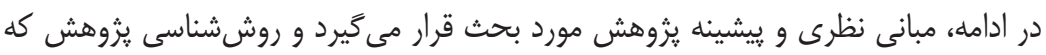

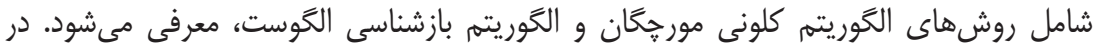

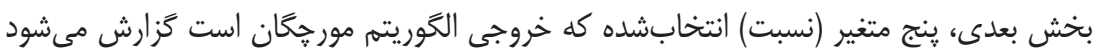

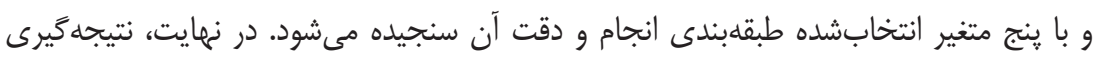
متناسب با خروجىهاى بلدستآمده بحث و تفسير مىشود.

\section{مبانى نظرى ثيزوهش}

يِيشينى ورشكستى از مسائل مهرم علوم مالى و مديريت است، كه هميشه توجه يزوهشكران را به خود جلب مى كند (Qu et al., 2019). با توسعه فناورى اطلاعات مدرن، زمينه براى استفاده

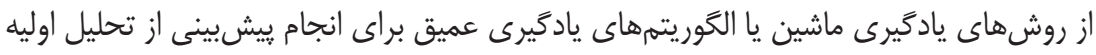
صورتهاى مالى فراهم مىشود. ارزيابى ريسك ورشكستكى تلاش مى كند كه با توجه به وضعيت

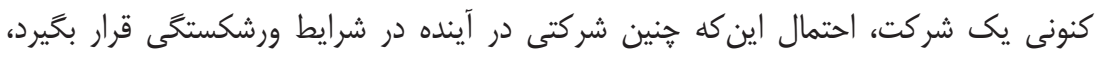

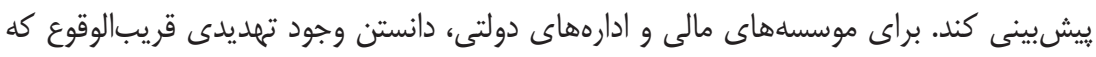
در اثر ورشكستخى مىتواند بهوجود بيايد، بسيار كليدى است (Zoričák et al., 2020).

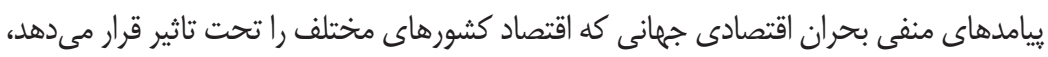
نقش اساسى ييشبينى ورشكستكى رابر جستهتر مى كند (Boratyńska \& Grzegorzewska, 2018).

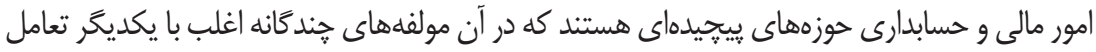

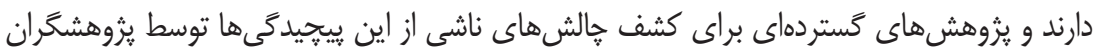

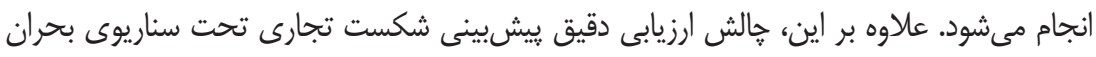




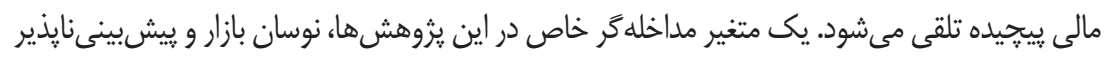

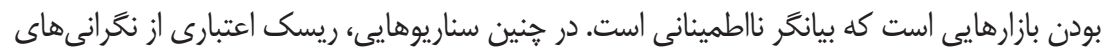

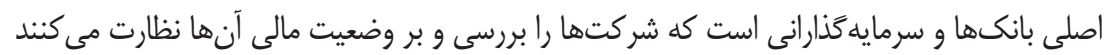
(Antunes et al., 2017)

ابزارى است كه ورشكستخى بر اساس آن بررسى مىشود (Alaka et al., 2018).

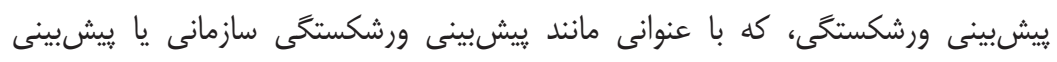

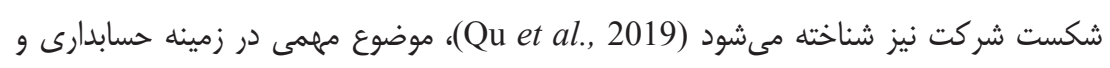

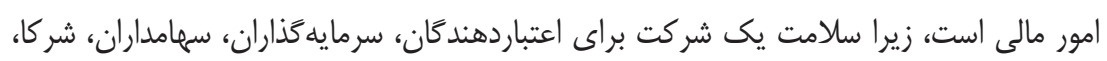

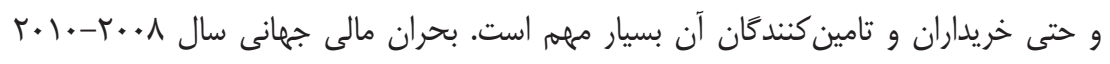

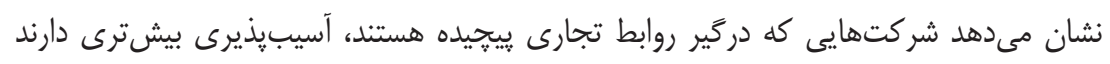

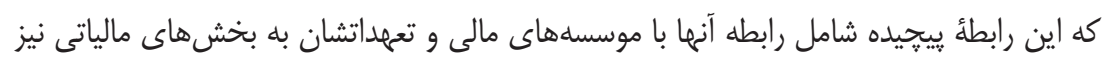

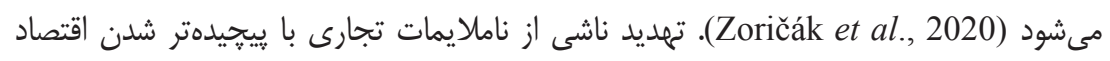

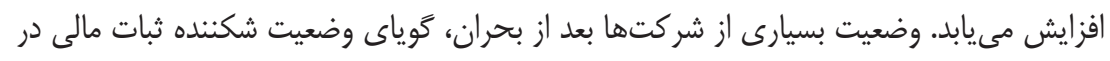

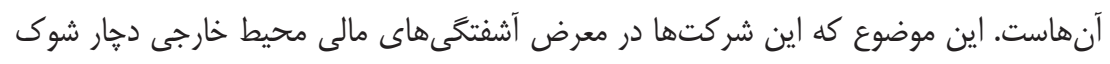
مالى مىشوند، ثابت است.

\section{مدل ها و شاخصهاى ريسك اعتبارى}

انتخاب بين الكوريتههاى يادگيرى كار دشوارى است و اغلب با توجه به در دسترس بودن

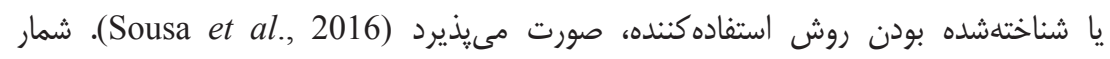

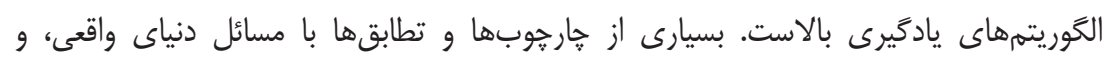

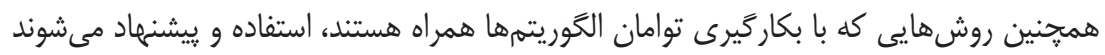

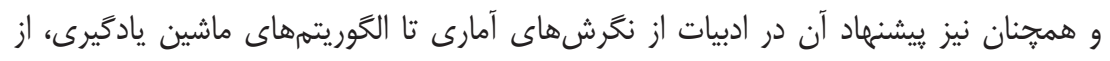

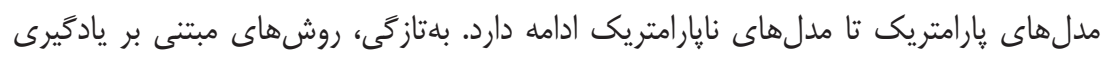

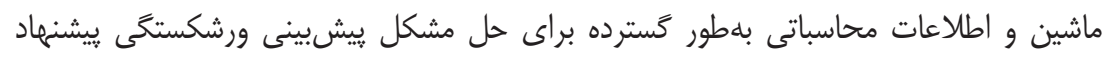

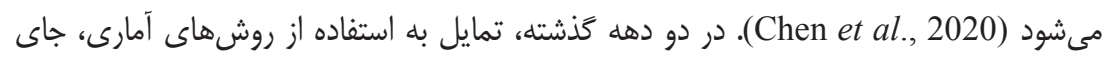

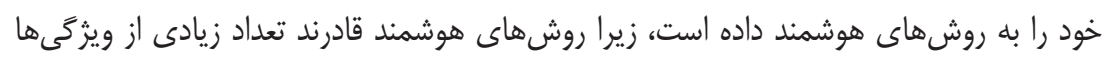

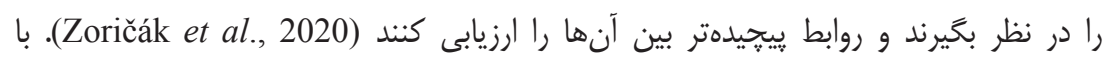
وجود تنوع روزافزون روشهاى هوشمند، جهار تكنيك شبكه عصبى، درخت تصميه، ماشين بردار 
يشتيبان، و استدلال موردمحور در ارزيابى متغيرها با استفاده از دادهها بيشترين استفاده را دارند (Wang et al., 2014)

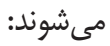

تحليل مميزى جندكانه (MDA)': تحليل مميزى جندكانه از يك تركيب خطى از متغيرها،

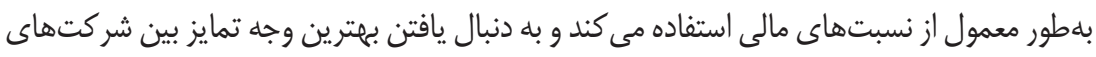
ناموفق و موفق است و شركتها را به يكى از اين دو گروه تقسيم مى كند.

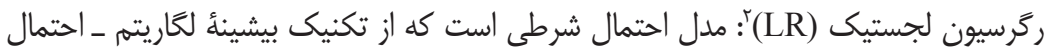
براى تخمين احتمال شكست شر كت استفاده مى كند. در اين مدل، فرض مى شود كه احتمال بازيرداخت

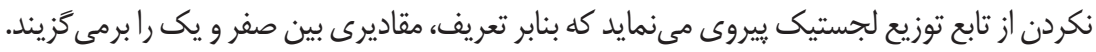

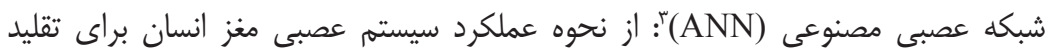

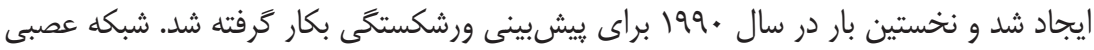
مانند "جعبه سياه" عمل مى كند و در شرايطى كه استخراج قوانين استنتاجى حاكم بر بديده (مانند احتمال نكول يك شركت)، سخت يا ناممكن باشد، مىتواند مفيد واقع شود.

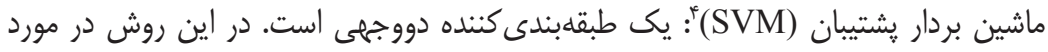
دو طبقه ابرصفحهاى ايجاد مىشود و مدل مى كوشد فاصله هر طبقه تا ابرصفحه بيشينه شود. اطلاعات نقطهاى كه كمترين فاصله را با ابرصفحه دارد، مبناى اندازهيرى است. اين الكوريته

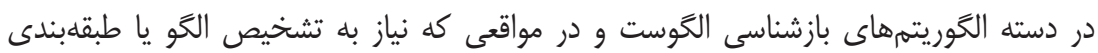
موضوعها وجود داشته باشد، بكار مىرود. مجموعههاى راف (RS)؛ه: فرض مدل بر اين معرد است كه اطلاعات مربوط به تمام اشيا (شركتها در موضوع ورشكستكى)، در يك محيط حل مسئله خاص وجود دارد و اين اطلاعات توسط برخى

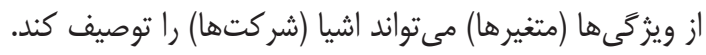

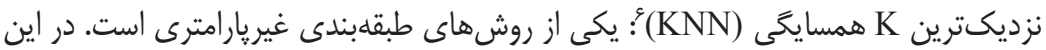

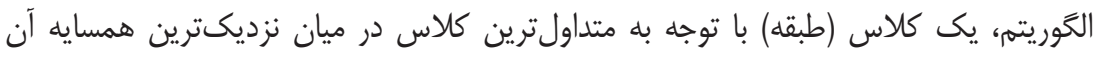

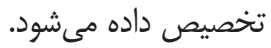

1. Multiple Discriminant Analysis

2. Logistic Regression

3. Artificial Neural Network

4. Support Vector Machines

5. Rough Sets

6. k-Nearest Neighbor 
استدلال موردمحور (CBR)': برخلاف مدلهاى مشابه يادگَيرى ماشينى به دنبال يافتن الكَو نيست، بلكه راهحل را بر اساس شباهت مورد به موارد مشابه ييشين يبيدا مى كند.

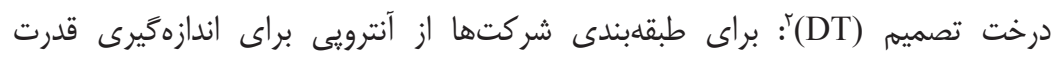
متمايز كنندگى متغير ها استفاده مى كند.

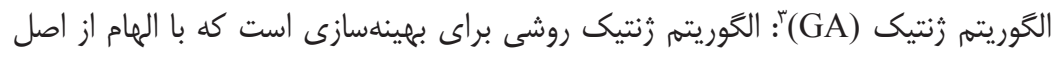

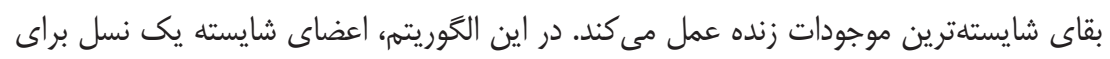
ايجاد نسلى از اعضاى بهاحتمال شايستهتر تركيب مى شوند.

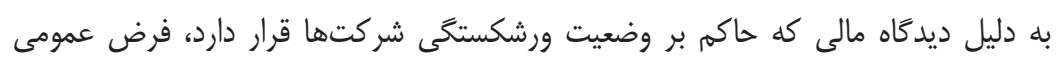

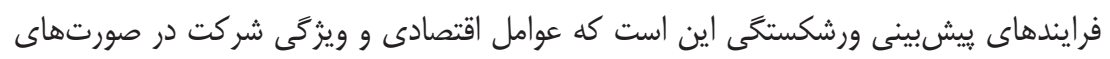

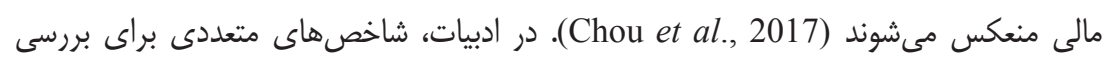

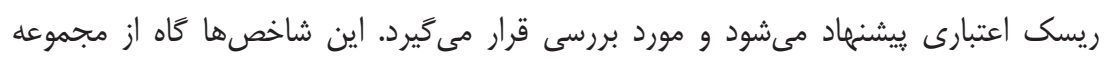

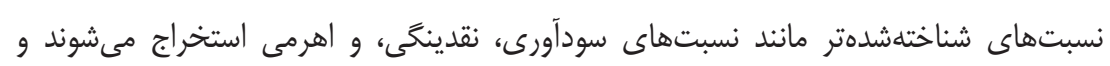

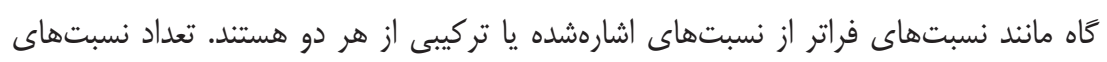

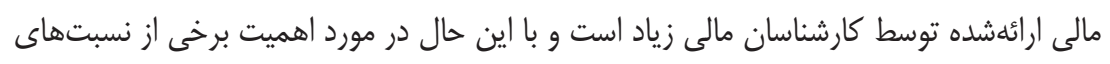

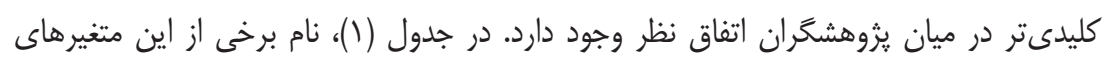

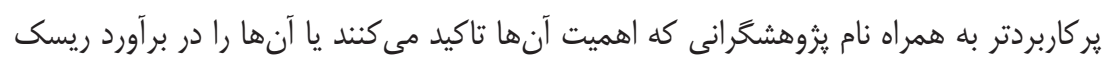

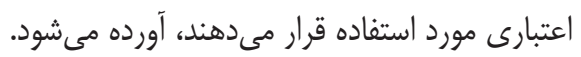

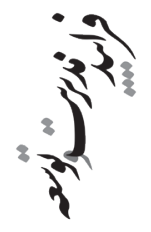

7
3
0
2
1
3
3
5
5
3
3
0
1
3
3
3
$=$

1. Case Based Reasoning

2. Decision Tree

3. Genetic Algorithm 


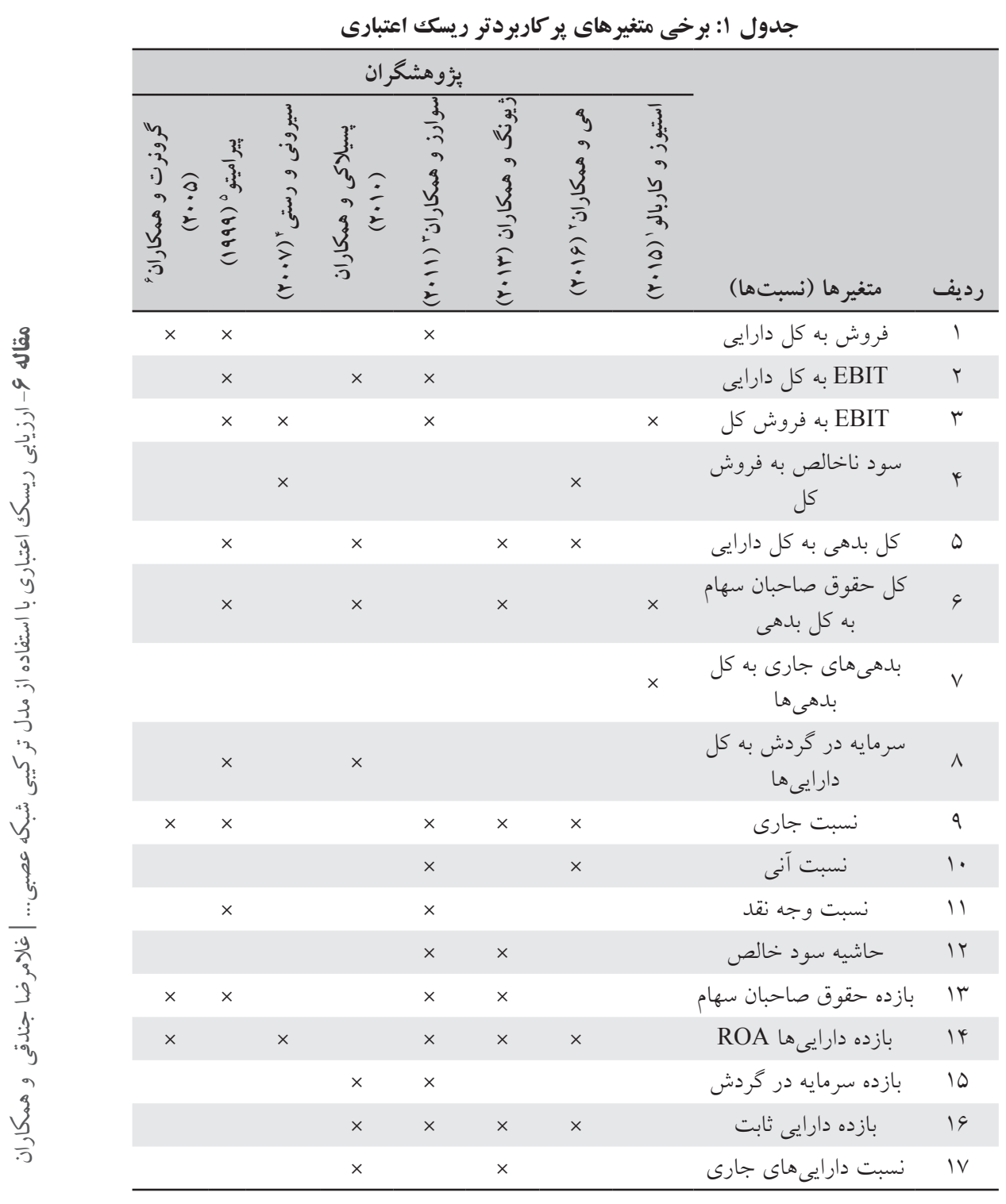

1. Estévez \& Carballo

2. He et al.

3. Soares et al.

4. Sironi \& Resti

5. Piramuthu

6. Grunert et al. 
ادامه جدول ا: برخى متغيرهاى ير كاربردتر ريسك اعتبارى

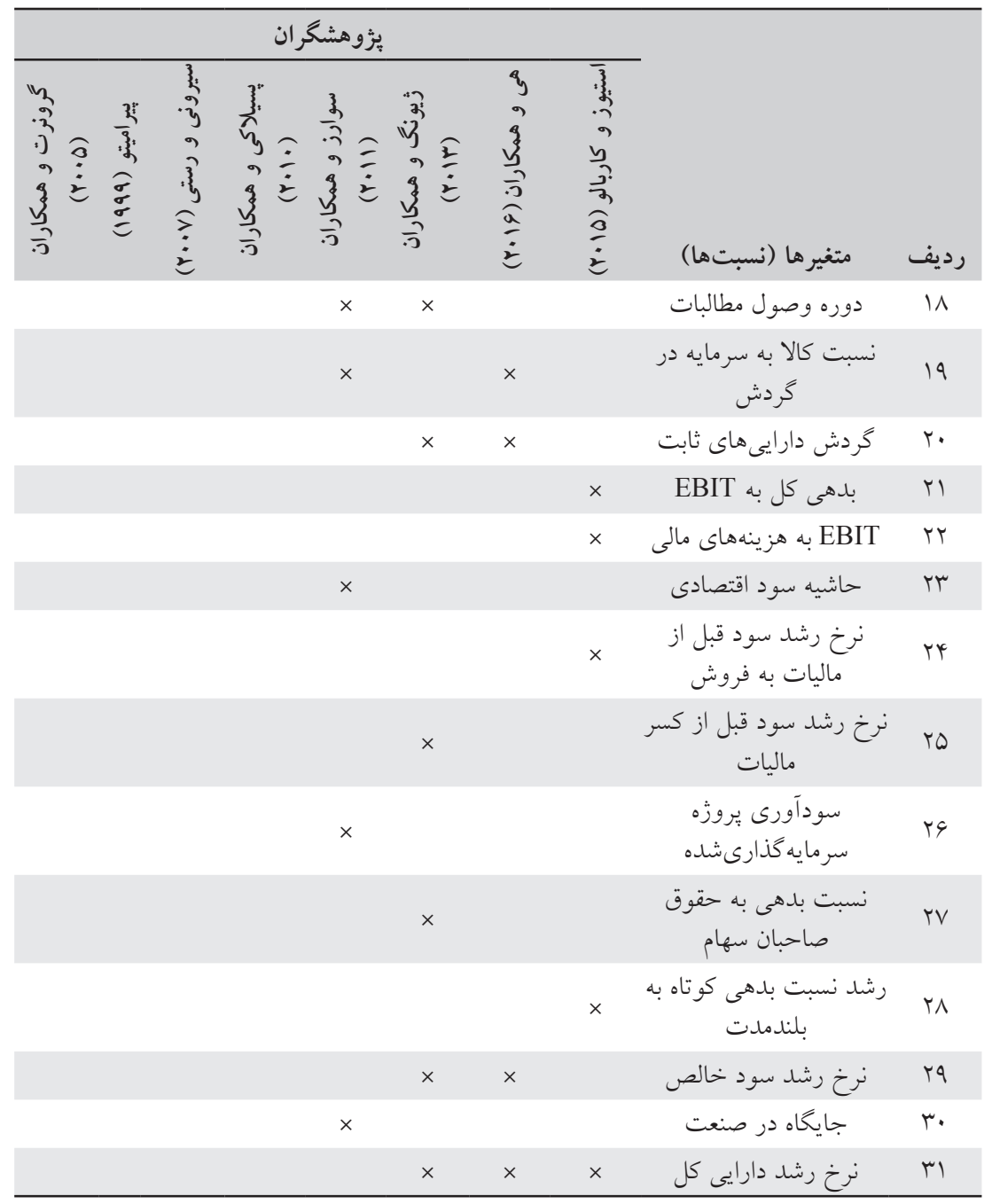

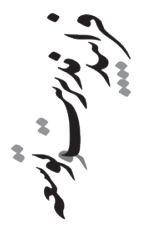

$\overline{2}$
2
0
2
2
1
3
0
0
1
$\because 3$
3
0
-1
3
3
$=$
$=$

انتخاب ويثز

هدف از ييشبينى ورشكستخى، ارزيابى شرايط مالى يك شركت و وضعيت آتى آن در زمينه

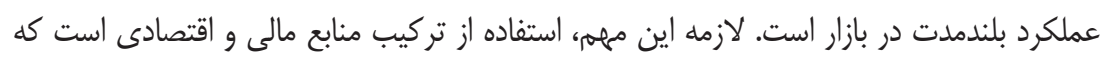


دانش كارشناسى در مورد يديده و دادههاى تاريخى شركتهاى موفق و ناموفق را با هم تركيب

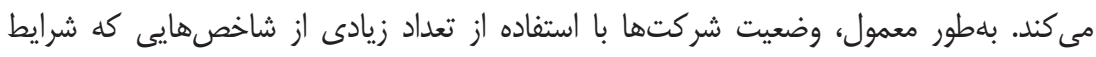
كسبوكار خود را توصيف مى كنند تعيين مىشود، كه اين دادهها بيشتر براى ايجاد يكى مدل

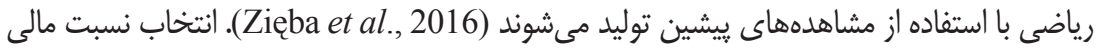

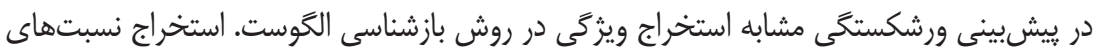

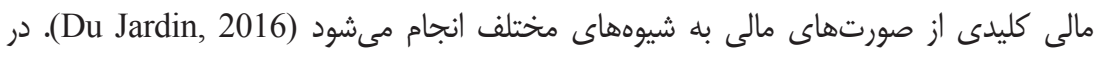

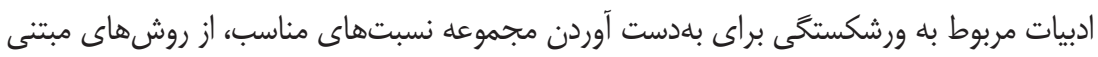

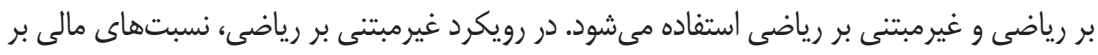

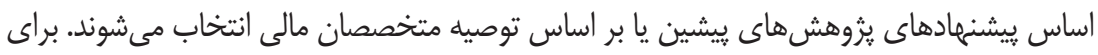

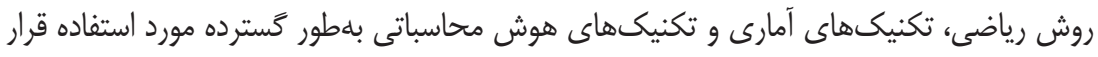

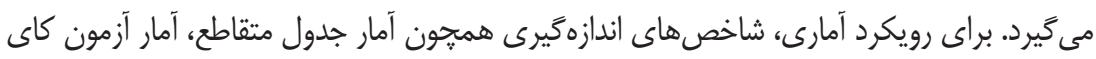

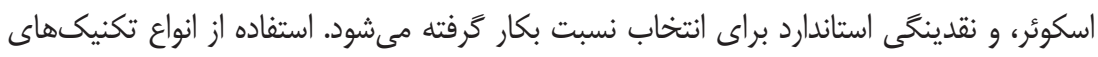

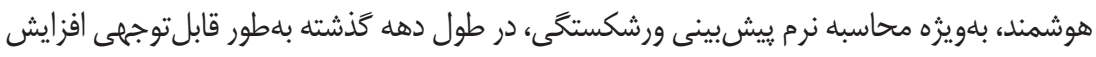

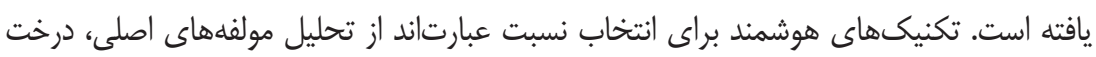

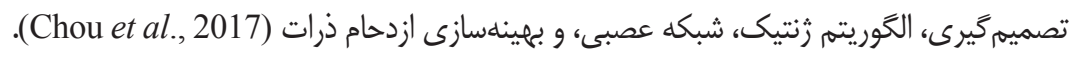

\section{مل ملهاى ويشبينى (طبقلبندى كننده)}

ورشكستخى شركتى يكى از محورهاى اصلى ريسك اعتبارى محسوب مى شود و بلطور ويثه

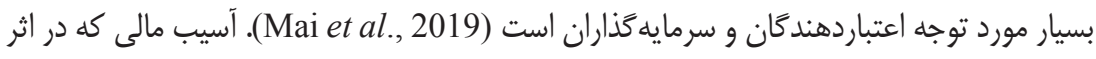
ورشكستكى شركتها مىتواند بر بيكر اقتصاد كشور وارد شود، بسيار قابل توجه است. بحران مالى

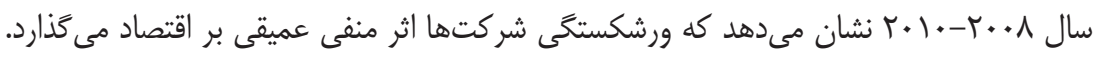

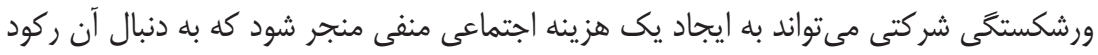

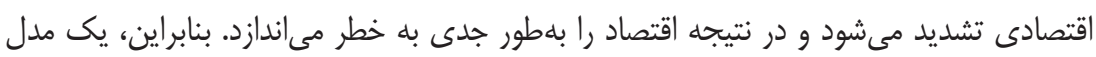

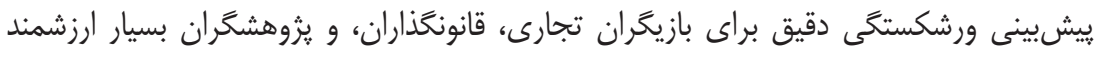

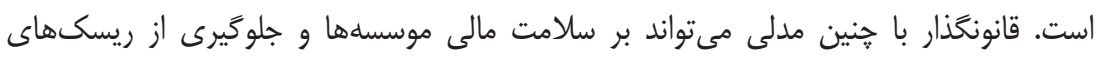

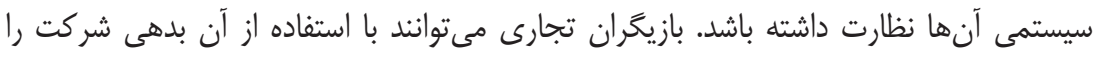

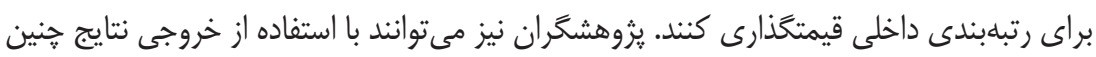

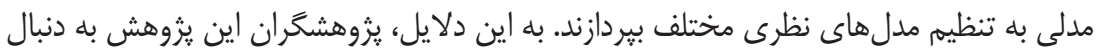


مدلهاى ييشيينى موثرتر براى ييشيينى ورشكستكى و بحران مالى هستند. مشخصه اصلى

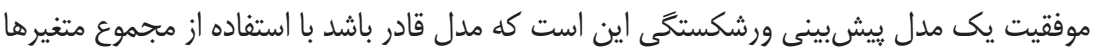

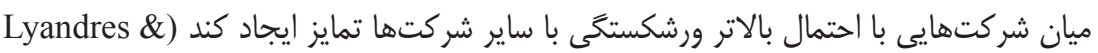

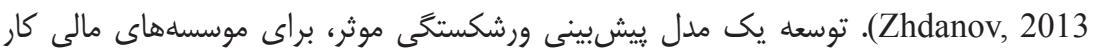

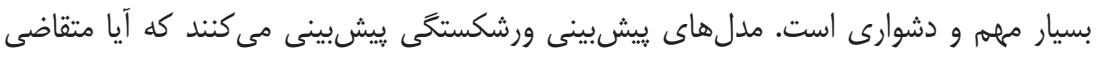

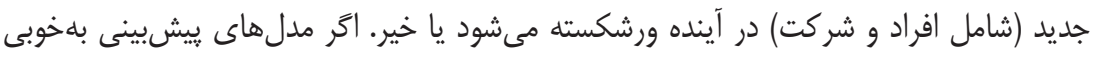

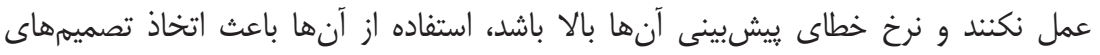

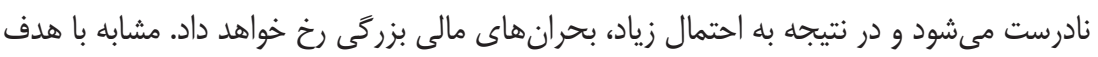

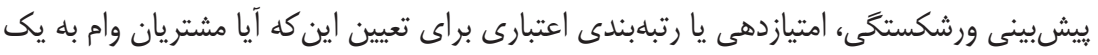

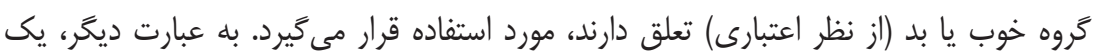
مدل نمر ددهى اعتبارى موثر مىتواند به إيجاد يك دستورالعمل مالى كمى كند كه تصميم بخيرد

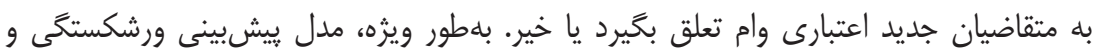

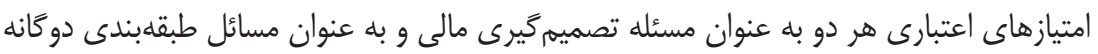

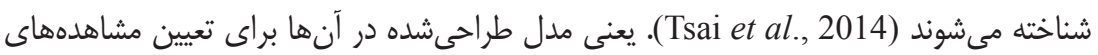

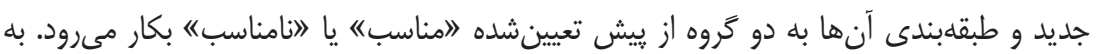

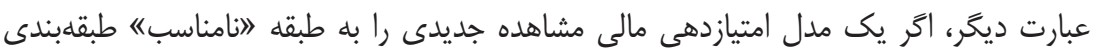

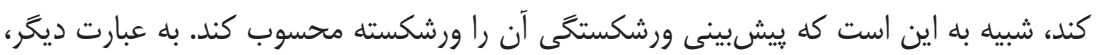

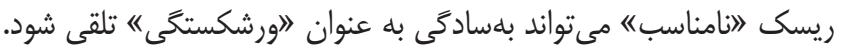

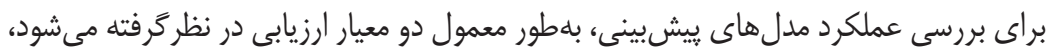

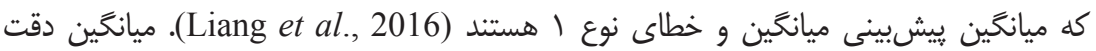

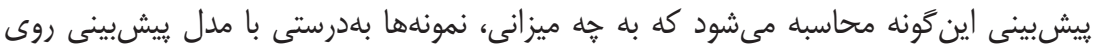

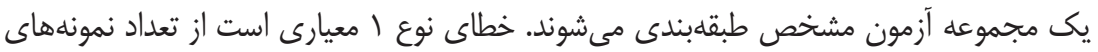
داده كه در آن مدل ييشبينى بلهور نادرستى يك شركت غيرورشكسته را در طبقه ورشكسته

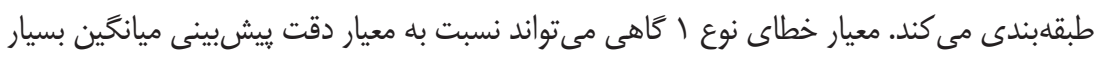

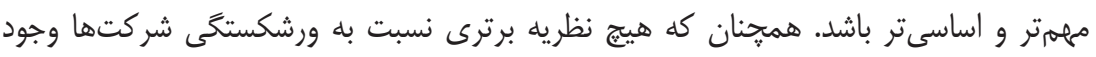

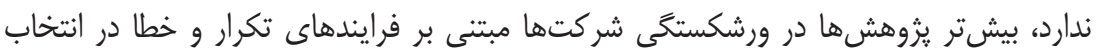

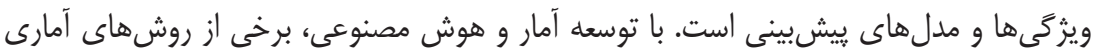

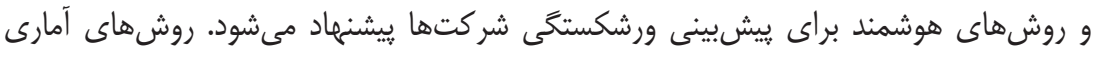


كه در ييشبينى ورشكستكى سازمانى بكار گرفته مىشوند عبارتاند از تحليل مميزى خطى،

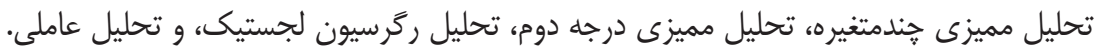

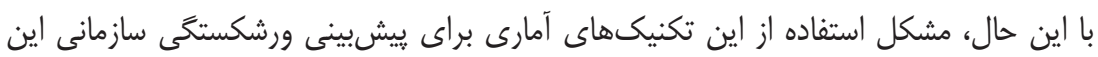
است كه برخى از فرضها، مانند فرضهاى نرمال جندمتغيره براى متغيرهاى مستقل، بيشتر

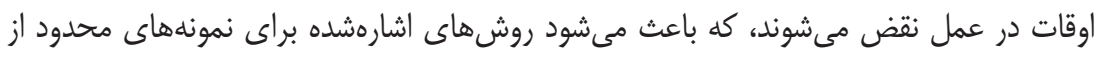

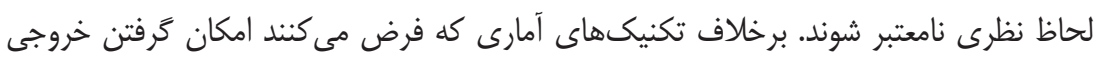

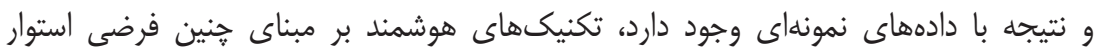

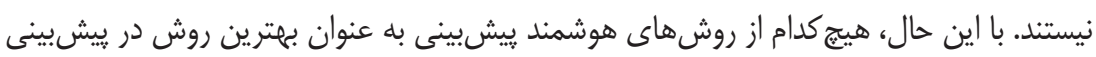

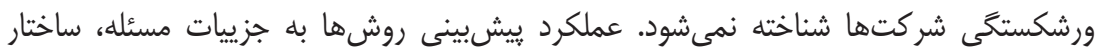

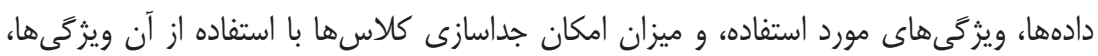

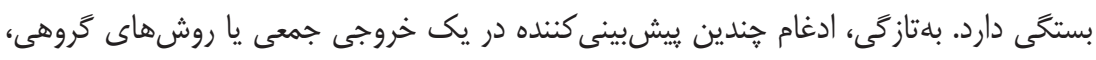

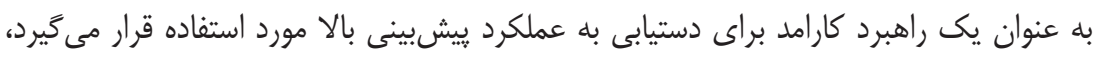

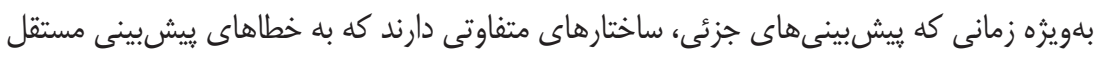
منجر مىشوند.

\section{شبكههاى عصبى}

شبكههاى عصبى (يا شبكههاى عصبى مصنوعى)، شامل واحدهاى يردازش اطلاعات و مشابه

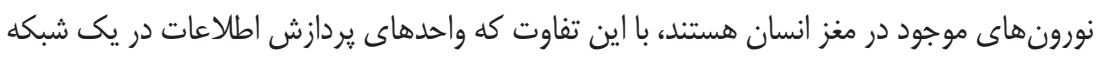

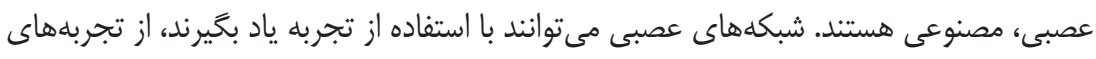
قبلى به افراد جديد تعميم يابند، و از اينرو تصميمهاى مفيدى اتخاذ كنند (Tsai et al., 2014).

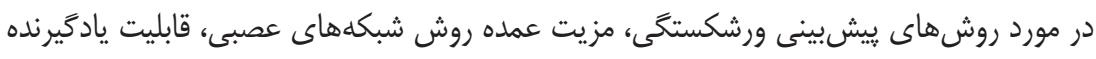

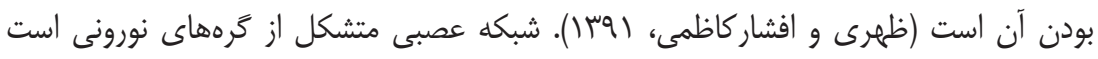

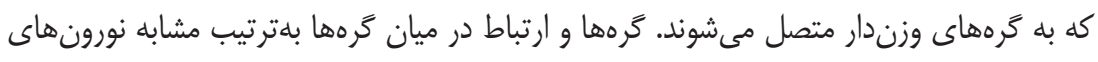

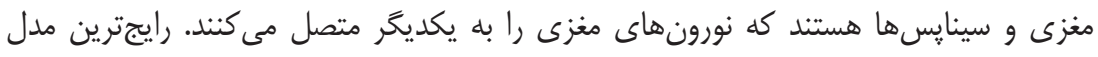

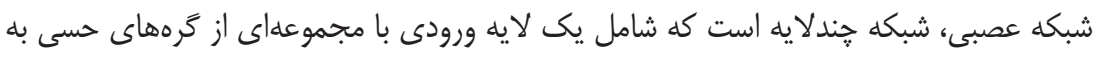

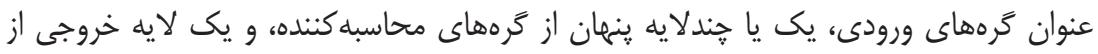

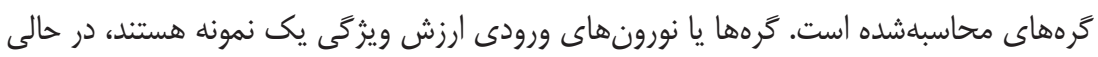
كه كَرهاى خروجى متمايز كنندة طبقه نمونه با طبقه ساير نمونهها هستند. 
الكوريتمهاى يادگيرى ماشين نسبت به مدلهاى آمارى براى ييشبينى ورشكستخى مناسبتر

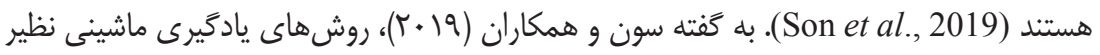
ماشين بردار يشتيبان و شبكه عصبى نسبت به روشهاى آمارى سنتى از دقت بالاترى برخوردارند. קن و همكاران (•r+r)، و زوريكاك و همكاران (•r+r)، نيز از دقت بالاتر روش هاى هوش محاسباتى نسبت به روشهاى آمارى سنتى و در نتيجه، تمايل بالاتر يروهشحًران در استفاده از

اين روشها مى خويند. هدف از انجام يثوهش حاضر، شناسايى مهرمترين متغيرهاى موثر در ريسك اعتبارى و به علاوه طبقهبندى شركتها بر اساس عوامل شناسايىشده و بررسى ميزان دقت بيشبينى مدل

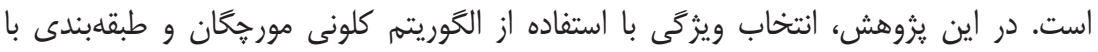

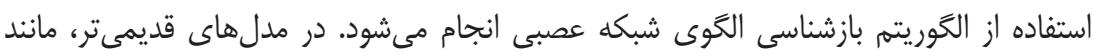
مدل درجلبندى بر اساس تحليل مميز خطى و مدل درجهبندى بر اساس رگرسيون لجستيك، وجه مشتركى وجود دارد و آن كوشش براى تعيين روابط بنيادينى است كه تعادل مالى ـ اقتصادى يك كـ

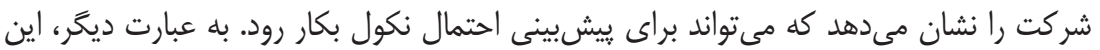

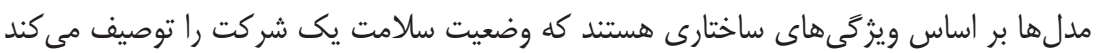
و انتخاب متغيرها، مرتبط با استفاده از سابقه تاثيرشان بر جنبههاى اقتصادى است. به همين دليل، مدلها بر اساس نخرش ساختارى شكل مى گيرند. به اين ترتيب كه توسط فرض يك تحليلخر

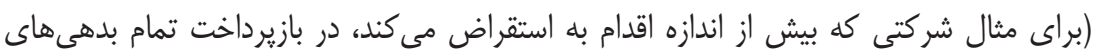
خود ناتوان است) ايجاد مىشود و سيس به دنبال تاييد اين فرضها در دادههاى يك نمونه واقعى هستند. در مقابل، شبكه عصبى از يك فرايند صرفاً قياسى استفاده مى كند، به اين شكل كه اگر در دادههاى نمونه، قاعده تجربى خاصى يافت شود، اين قاعده در ييشبينى نكول در آينده براى

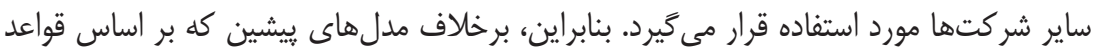

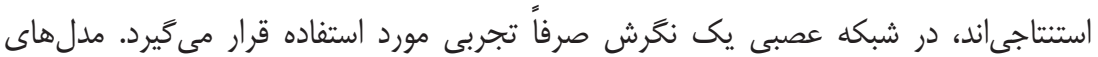
ساختارى بر اساس الخوريتهماى مشخص و اثباتشده هستند كه براى آزمونهاى استنباطى در تاييد اهميت ضرايب تخمينى مورد استفاده قرار مى گيرند. در مقابل، روشهاى مبتنى بر نخرش قياسى مانند شبكه عصبى مىتوانند مانند يك جعبه سياه عمل كنند و در شرايطى كه استخراج قوانين استتاجى حاكم بر يك يديده (همجون احتمال نكول يك شركت)، سخت يا ناممكن باشد،

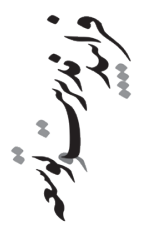




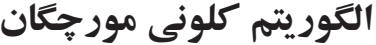

ايده الكوريتم كلونى مورحه، تقليد اين رفتار با مورجههاى شبيهسازىشداى است كه در اطراف نمودار راه مىروند، و موجب حل مسئله مىشوند. مزيت آن نسبت به روش زئنيكى زمانى

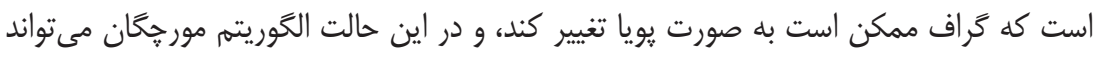

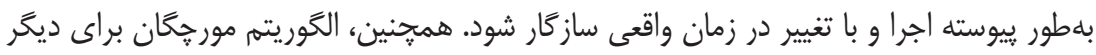

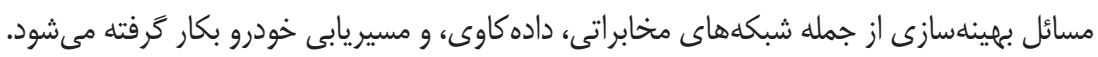

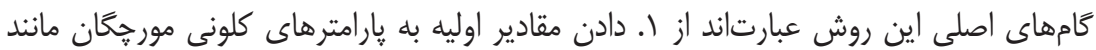

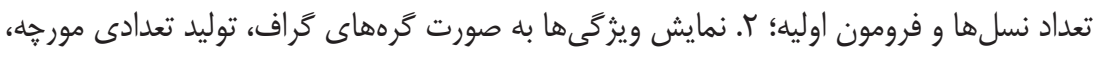

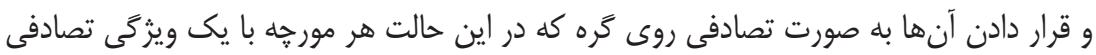

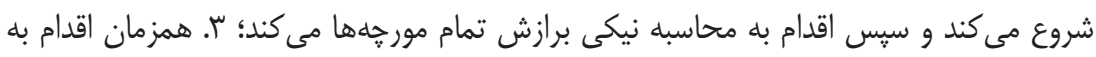

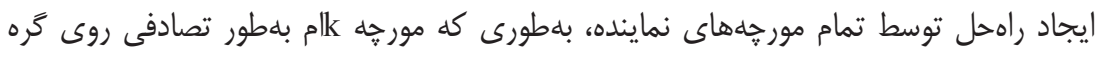

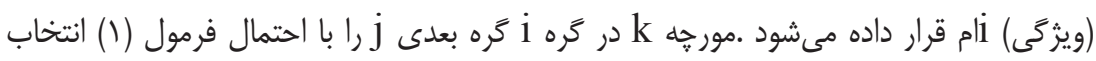

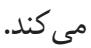

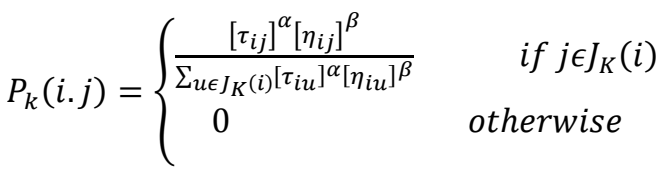

كه در اينجا

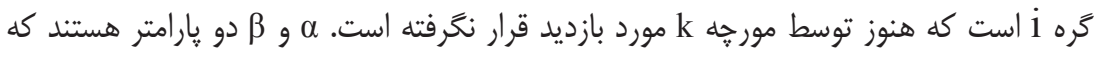

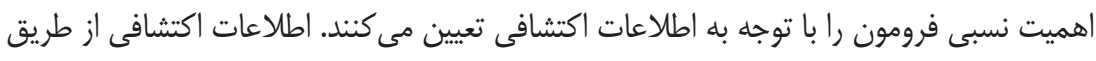
$\eta_{i j}=\frac{\sum_{n=1}^{N} x_{n i} x_{n j}}{\sqrt{\sum_{n=1}^{N} x_{n i} x_{n j}}}$

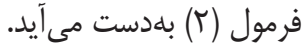
تعداد كل نمونههاى آموزشى است. كره بعدى j به صورت فرمول (َّ) اضافه مىشود: $j=\left\{\begin{array}{lr}\operatorname{argmax}_{u \in J_{k}(i)\left\{\left[\tau_{i u}\right]^{\alpha}\left[\eta_{i u}\right]^{\beta}\right\}} & \text { if } q \leq q_{0} \\ J & \text { if } q>q_{0}\end{array}\right.$

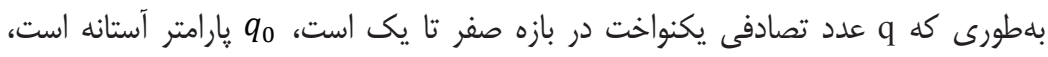
JલJJ $(i)$ 
بعدى، زيرمجموعه ويزگ جدى جديد بهدست مى آيد و محاسبه نيكى برازش مورجه انجام مىشود. اكر

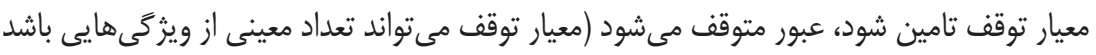

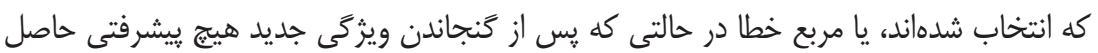

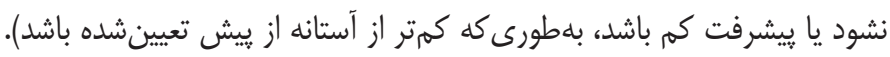

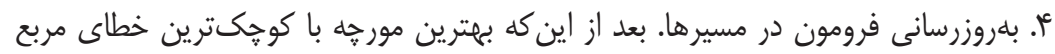

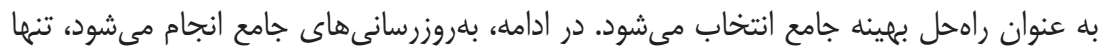

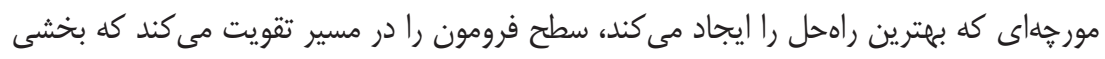

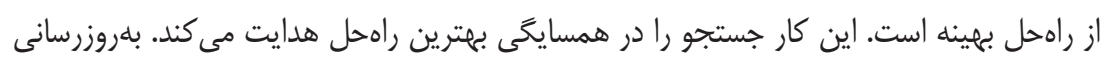

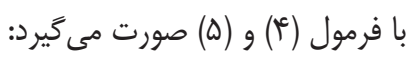
$\rho \Delta \tau_{i j}+(1-\rho) \tau_{i j} \rightarrow \tau_{i j}$

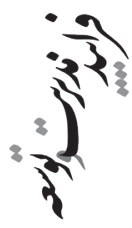

$\Delta \tau_{i j}=\left\{\begin{array}{lll}\frac{Q}{J_{\min }} & \text { if } & \{i j\} \in S^{+} \\ 0 & \text { if } & \{i j\} \notin S^{+}\end{array}\right.$

菌

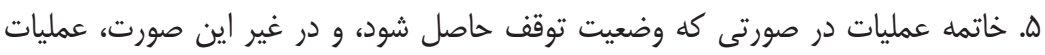

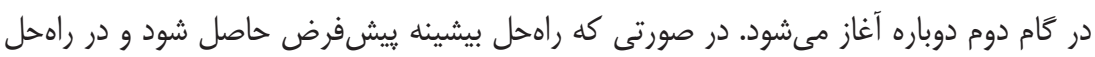

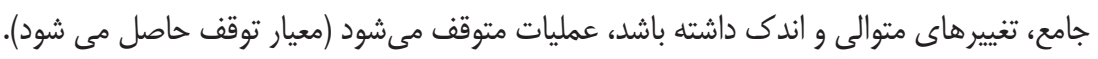

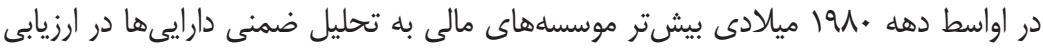

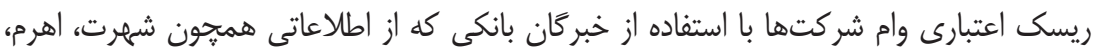

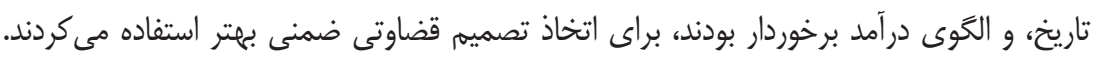

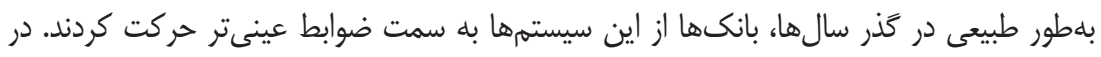

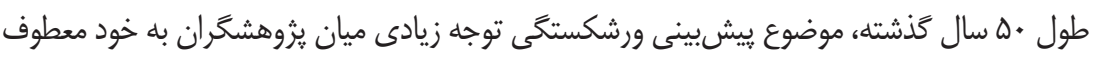

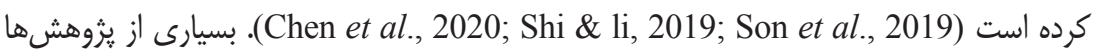

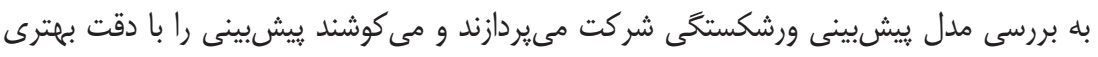

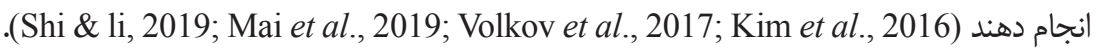

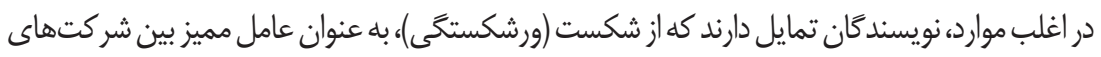

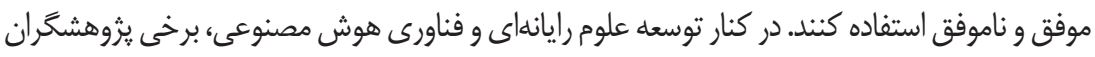
از تكنيكهاى يادَيرى ماثين براى ساخت مدلهاى بيشينى ورشكستكى استفاده مى كنند 
(Chou et al., 2017; Liang et al., 2016; Wang et al., 2014; Chen et al., 2011) ديخر بلطور خاص دو يا سه تكنيك يادگيرى ماشين را براى مدلسازى ييشبينى ورشكستخى مقايسه

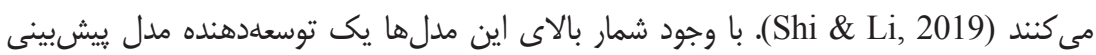
ورشكستگى بايد قدرت و محدوديتهاى ابزار و تكنيكهاى موجود را از جنبههاى مختلف شامل

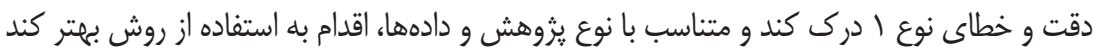
(Alaka et al., 2018)

جدول r: خلاصه برخى ثزوهشهاى حوزه ريسك اعتبارى

\begin{tabular}{|c|c|c|c|}
\hline نتايج & روشهاى مورد & هدف & بُروهشخران (سال) \\
\hline 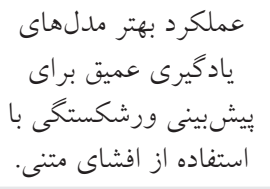 & مدلهاى يادگيرى & 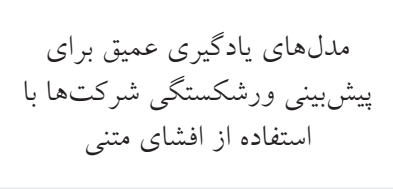 & $\begin{array}{c}\text { ماى و همكاران } \\
(Y \cdot 19)\end{array}$ \\
\hline برآورد ورشكستكى با با درصد. & 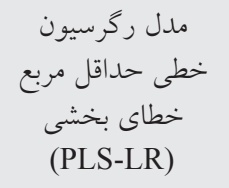 & 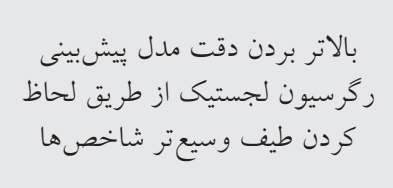 & جابور (Y.IV) \\
\hline 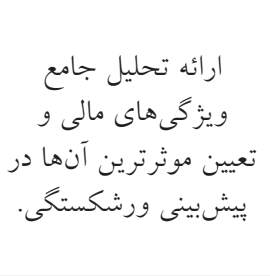 & 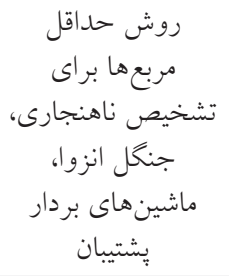 & 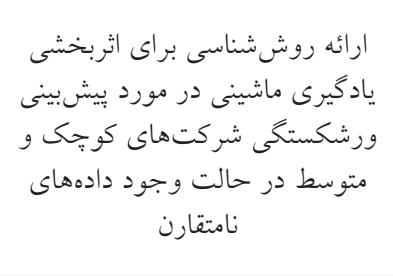 & 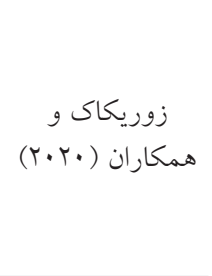 \\
\hline 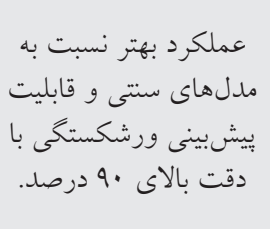 & خ خبكه عصبى & 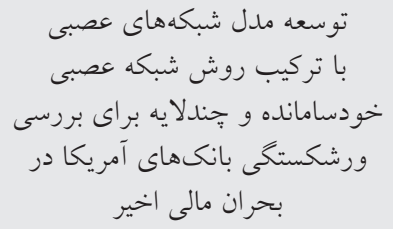 & سانز 'ايتورياگًا و \\
\hline افق سهساله نسبت بيشى به در مداى مشابه. & رشكه عصبى، تحليل & ارائه مدلى براى افزايش افق بيشى ازينى سال & $\begin{array}{l}\text { دو جاردين } \\
(Y \cdot \mid(0)\end{array}$ \\
\hline
\end{tabular}

1. Iturriaga \& Sanz 
ادامه جدول r: خلاصه برخى بثوهشهاى حوزه ريسك اعتبارى

\begin{tabular}{|c|c|c|c|}
\hline نت & روش استفادى مورد & هدف & يثروهشخر ان (سال) \\
\hline 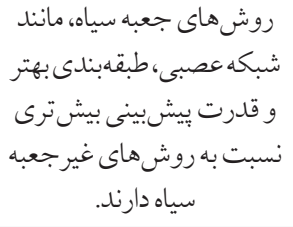 & 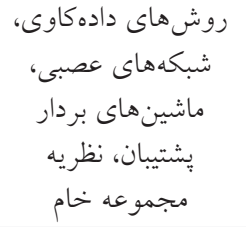 & 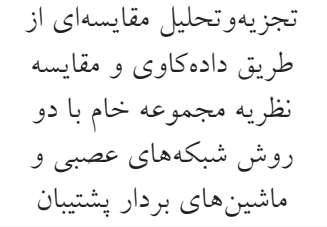 & 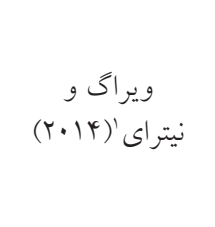 \\
\hline مالى دياز به اصلاح سيستمهاى منطقه MENA. & هموار (PSTR) & 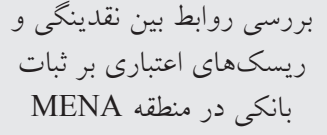 & 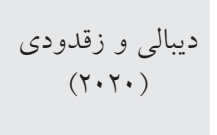 \\
\hline 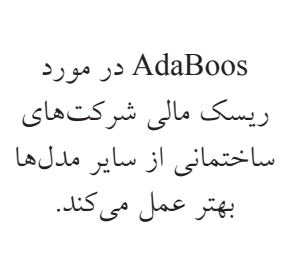 & 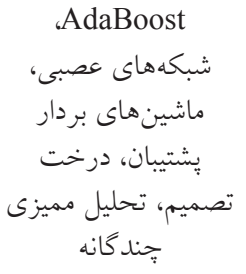 & 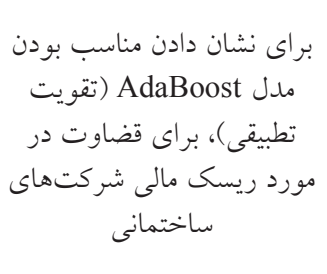 & 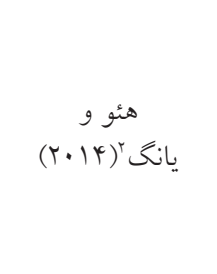 \\
\hline 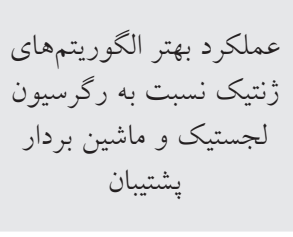 & راشوريتمهاى زيتيك، & 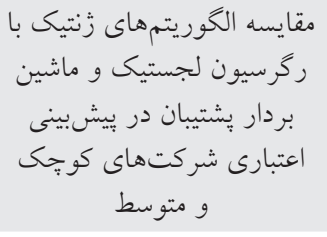 & كردينى $)^{r}(r \cdot \mid r(r)$ \\
\hline 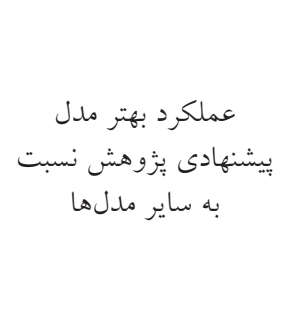 & $\begin{array}{c}\text { خوشتفاده از الخوريتمى جندهدفه } \\
\text { Multi-Objective } \\
\text { Soft Subspace } \\
\text { Clustering } \\
\text { (EMOSSC) } \\
\text { Algorithm }\end{array}$ & 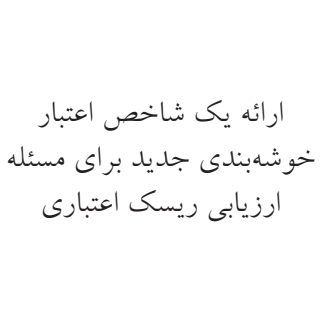 & 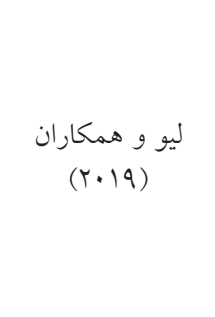 \\
\hline 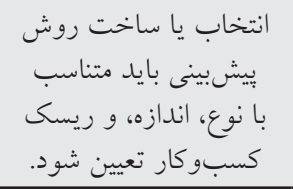 & 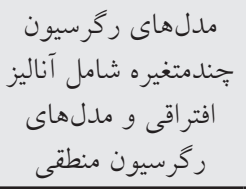 & 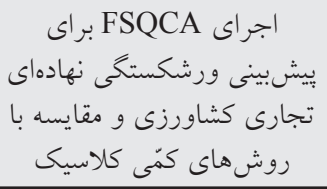 & 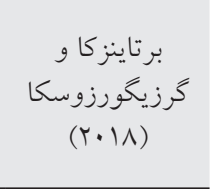 \\
\hline
\end{tabular}

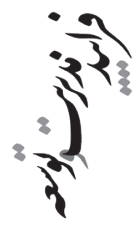


ادامه جدول r: خلاصه برخى يزوهشهاى حوزه ريسك اعتبارى

\begin{tabular}{|c|c|c|c|}
\hline نتايج & روش استفادى مورد & هدف & يُخوهشخران (سال) \\
\hline 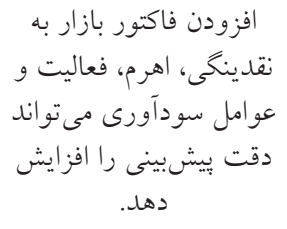 & رگرسيون لجستيك & 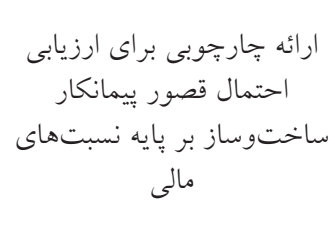 & 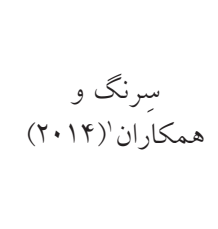 \\
\hline 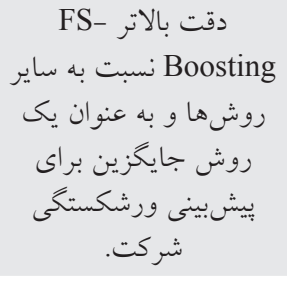 & 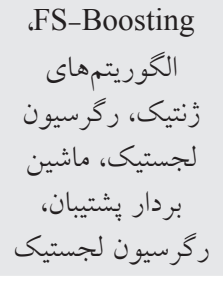 & 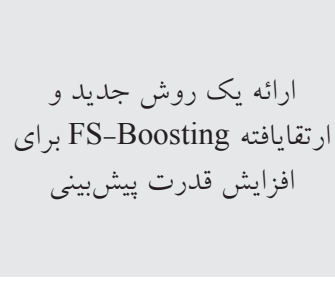 & $\begin{array}{c}\text { وانگ و همكاران } \\
(Y \cdot \mid Y)\end{array}$ \\
\hline عمليشنهرد بهتر مدل تركيت به مدلى & خوشهبندى فازى، الكوريتم & 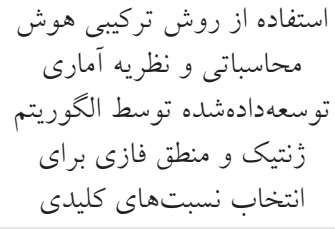 & $\begin{array}{c}\text { : جو و همكاران } \\
(Y \cdot I V)\end{array}$ \\
\hline 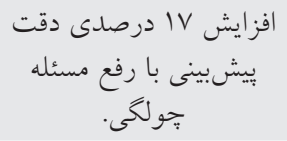 & $\begin{array}{l}\text { مصنوعى و درخت عصبى } 1 \text { مoosting } \\
\text { Booring }\end{array}$ & 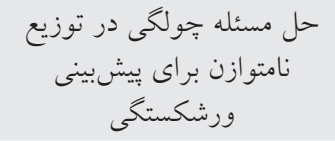 & $\begin{array}{c}\text { سون و همكاران } \\
\text { (Y.19) }\end{array}$ \\
\hline 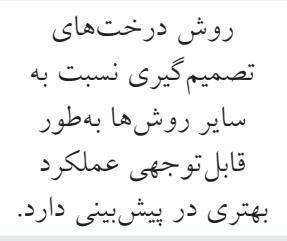 & 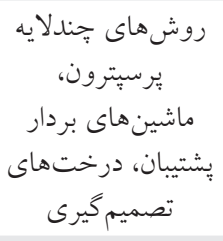 & به منظور مقايسه روشهاى & 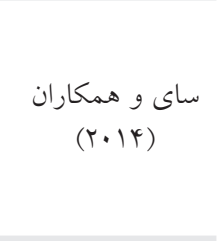 \\
\hline 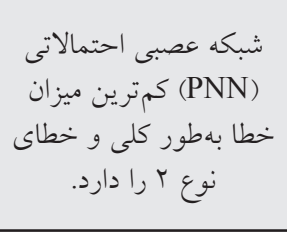 & 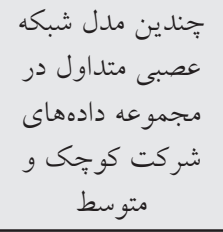 & 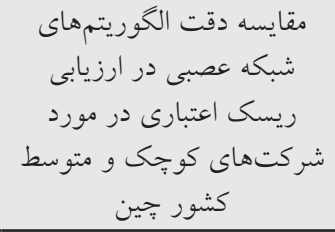 & 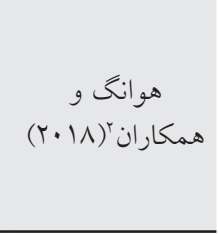 \\
\hline
\end{tabular}

1. Tserng et al.

2. Huang et al. 
همان طور كه در جدول (T) مشاهده مى شود، بيشتر يزوهش هاى حوزه ييشبينى ورشكستخى با

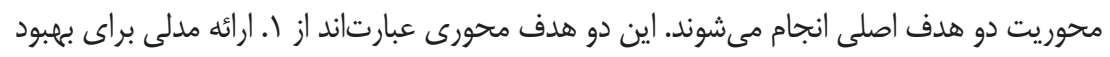

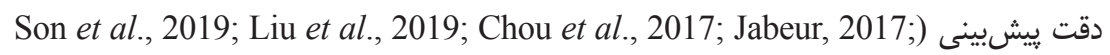
خاص (Du Jardin, 2015 و r. مقايسه روش هاى مختلف ييشبينى متناسب با يك جامعه آمارى يا رويكرد

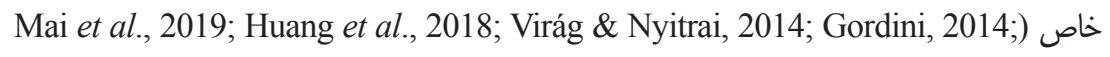
(Tsai et al., 2014

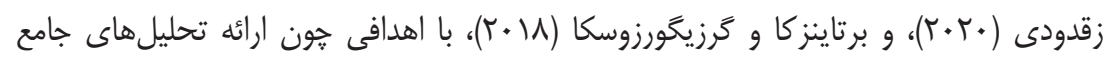
انجام مىشوند.

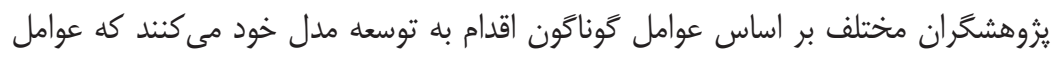

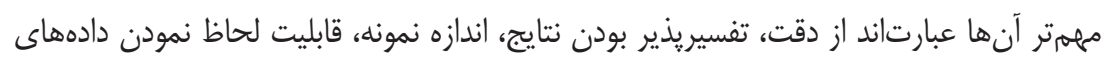

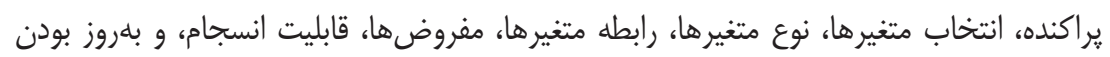

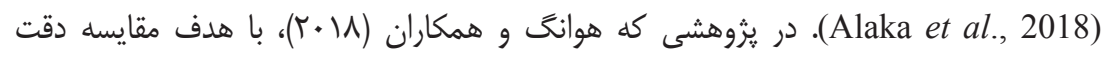

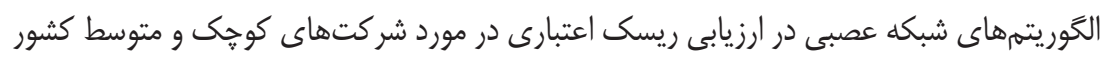

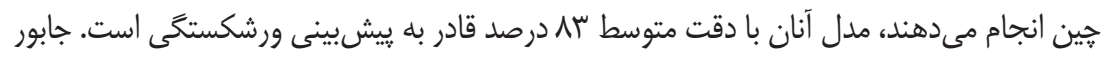

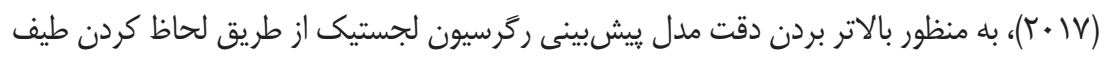

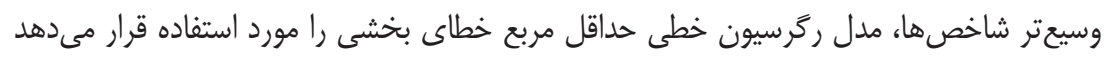

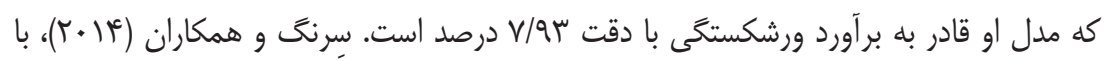

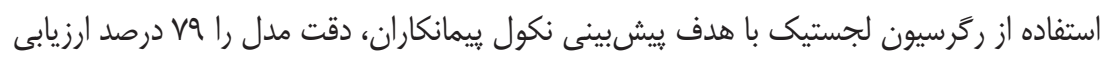

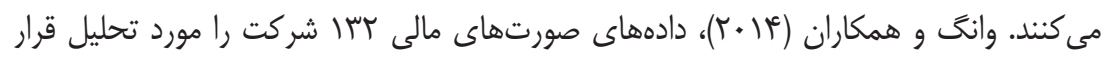

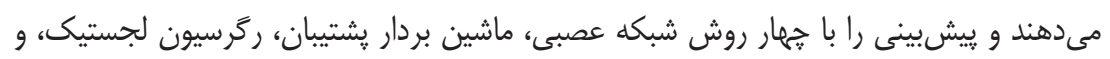

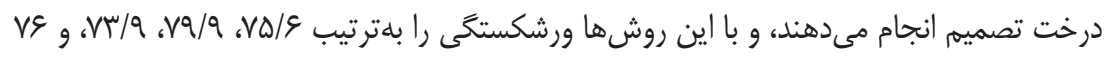

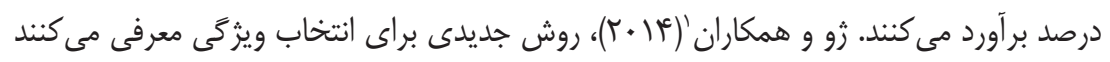

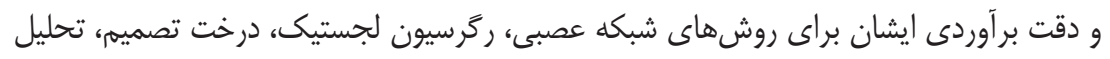

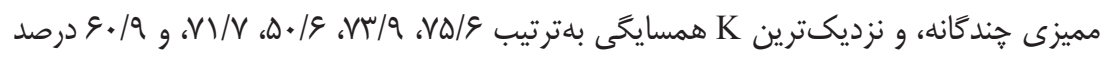

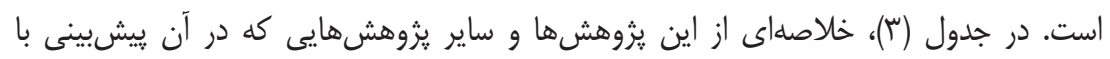
روشهاى مختلف تخمينزده شده باشد، نمايش داده مى آشود.

1. Zhou et al. 
جدول ب: خلاصةٌ ئزوهشهاى بر آورد دقت ييشبينى احتمال ورشكستىى

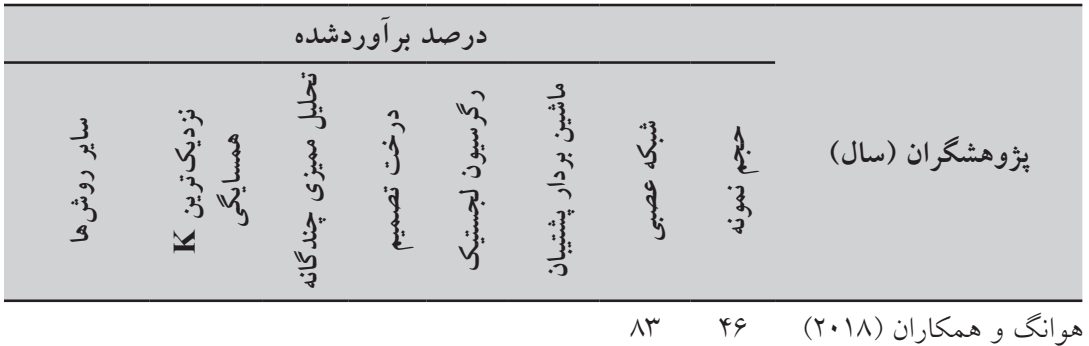

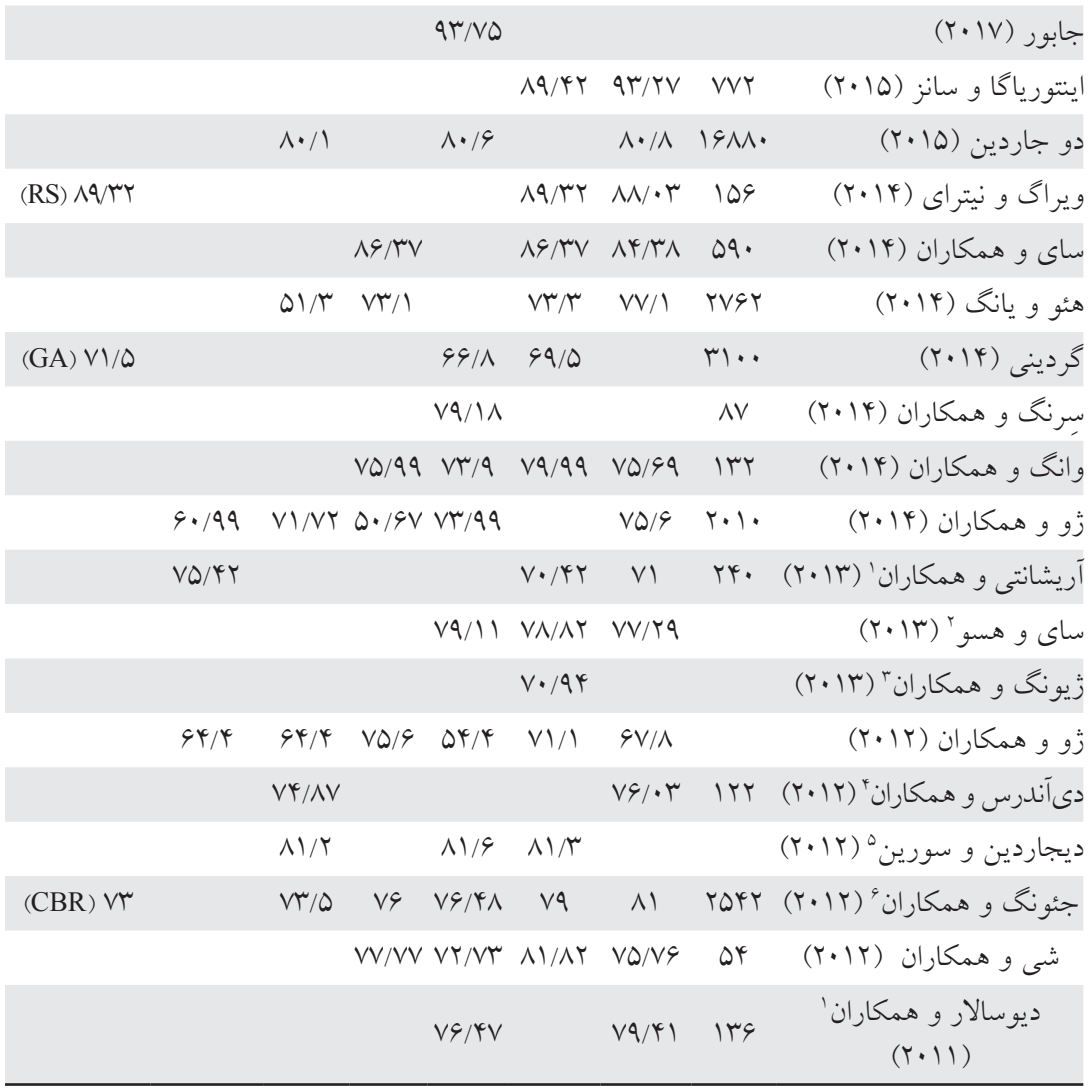

1. Arieshanti et al.

2. Tsai \& Hsu

3. Xiong et al.

4. De Andrés et al.

5. Du Jardin \& Séverin

6. Jeong et al. 
ادامه جدول بّ: خلاصة ئوهشهاى بر آورد دقت بيشيينى احتمال ورشكستكى

\begin{tabular}{|c|c|c|c|c|c|c|c|c|}
\hline \multicolumn{8}{|c|}{ درصد بر آوردشده } & \multirow[b]{2}{*}{ يزّوهشخران (سال) } \\
\hline $\begin{array}{c}3 \\
3 \\
3 \\
3 \\
3 \\
3\end{array}$ & 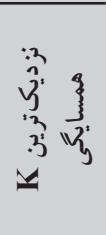 & 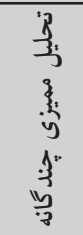 & $\begin{array}{l}\hat{3} \\
3 \\
3\end{array}$ & $\begin{array}{l}13 \\
3 \\
3 \\
3 \\
3 \\
3\end{array}$ & 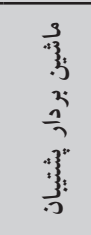 & 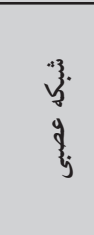 & $\frac{1}{3}$ & \\
\hline \multirow[t]{2}{*}{ (GA) } & VN/VQ & & & & $V 9 / 9 \mathrm{~V}$ & $V Q / D \Lambda$ & rY. & جن و همكاران (11) \\
\hline & & & & & vq & VN/Tr & Ir. & يانگ و همكار انج (111) \\
\hline \multirow[t]{4}{*}{$(\mathrm{CBR}) V \mu / V$} & & $v \cdot / l$ & & $v \cdot / l$ & $V 4 / T$ & $V M / l$ & $1 \cdots$ & 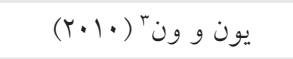 \\
\hline & & & & & & $V Y / \cdot r$ & $\mid \& \Delta \Lambda$ & 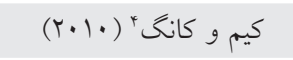 \\
\hline & & & $90 / \mathrm{V}$ & $V Y / T$ & & $V Y / \Lambda$ & $1 \cdots$ & جو و همكارانه (· (Y.1) \\
\hline & & & & & & $\Lambda V / \Delta$ & $\Delta A^{*}$ & ناظمى اردكانى (Irq4) \\
\hline
\end{tabular}

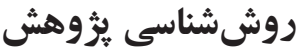

با مطالعات كتابخانهاى و مرور ادبيات، متغيرهاى اثركذار در حوزه ريسك اعتبارى شناسايى

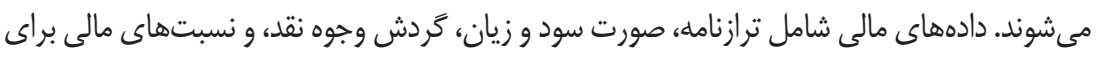

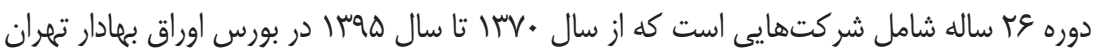

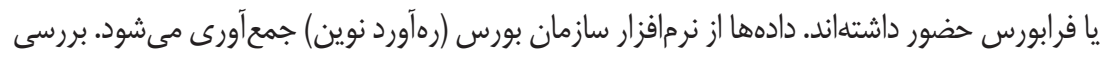

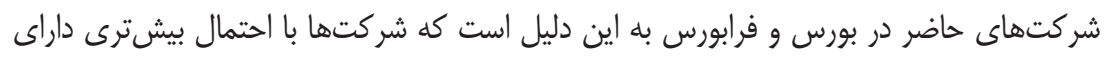

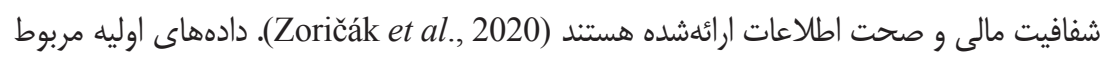

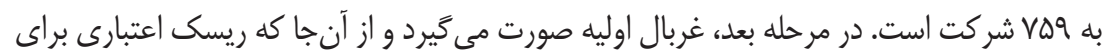

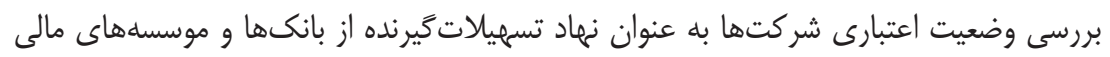

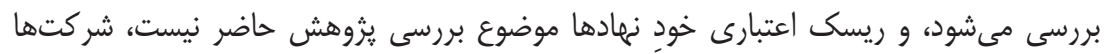

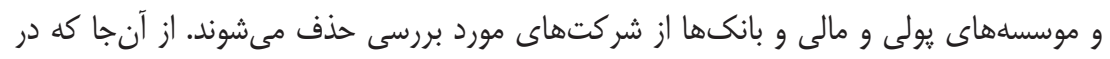

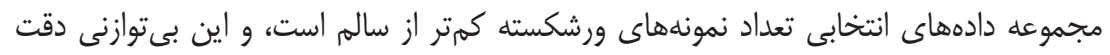

1. Divsalar et al.

2. Yang et al.

3. Yoon \& Kwon

4. Kim \& Kang

5. Cho et al. 
مدل را كاهش مىدهد (Volkov et al., 2017; kim et al., 2016)، از دادههاى ثانويه براى بررسى وضعيت شركتهاى سالم و ورشكسته استفاده مىشود كه اين دادهاى ثانويه شامل كل

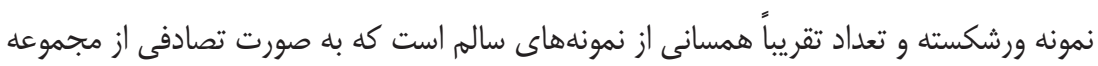

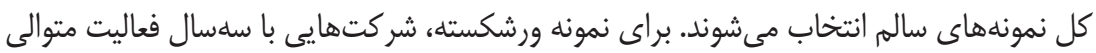

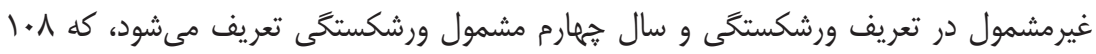

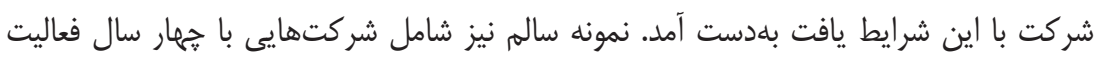

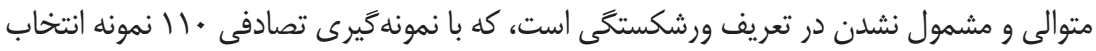

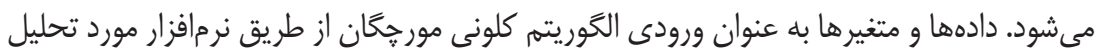

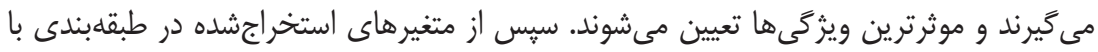

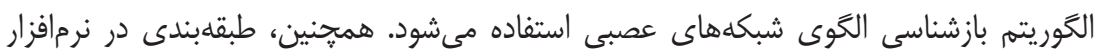

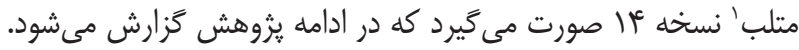

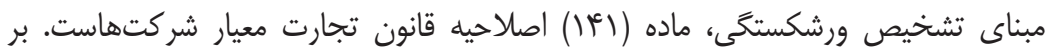

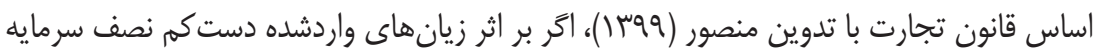

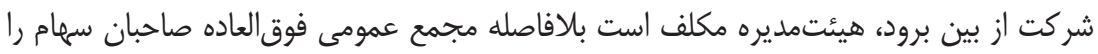

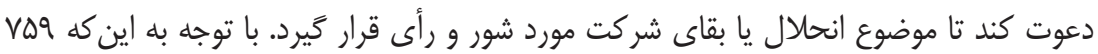

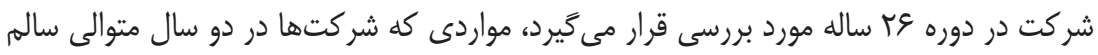

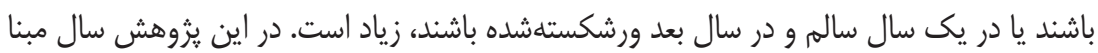

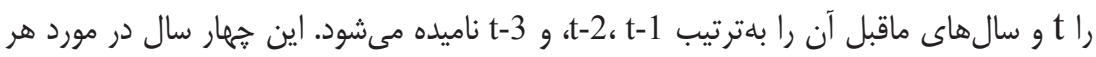

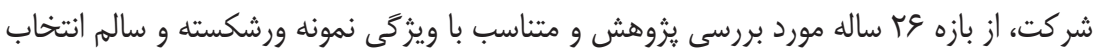

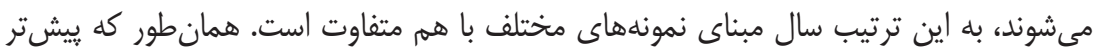

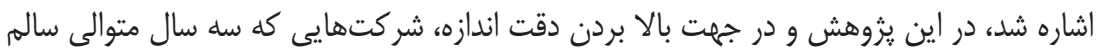

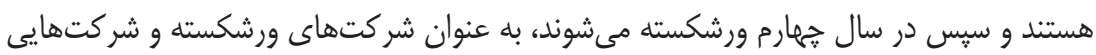

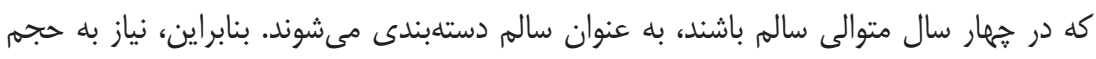

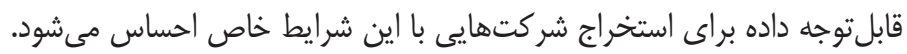




\section{دادهها و آمار توصيفى}

براى استخراج بااهميتترين عوامل موثر بر ريسك اعتبارى، شاخصها از ادبيات استخراج

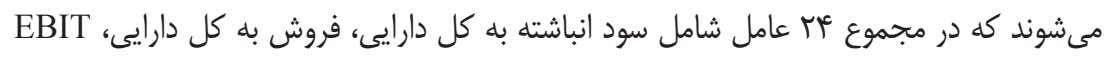

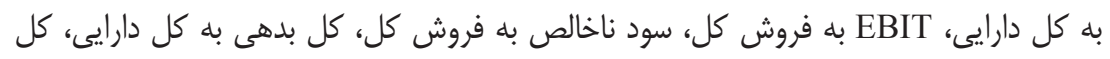

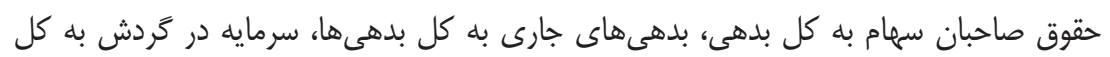

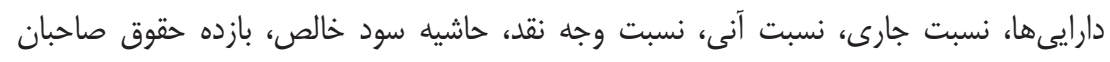

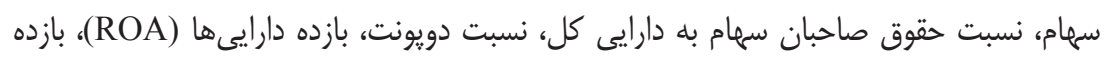

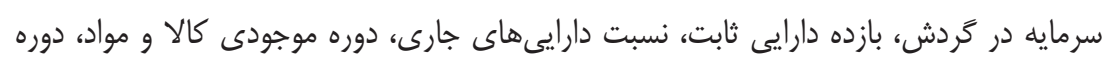

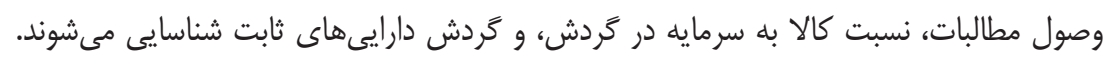

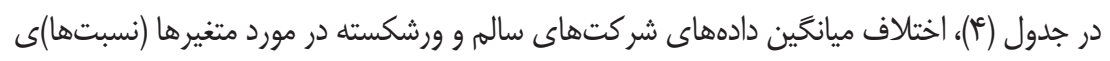
اشارهشده آورده مى شود.

جدول †: اختلاف ميانكين دادههاى شر كتهاى سالم و ورشكسته

\begin{tabular}{|c|c|c|c|c|c|c|}
\hline قدرمطلق & كيانخين & شر ميانگين & شر كت هانين & اختصام & متغير ها (نسبت ها) & رديف \\
\hline$\% 194$ & $\cdot / \cdot \mu r$ & $-\cdot / \cdot v 1$ & $\cdot / 1 \mu \wedge$ & $\mathrm{RE} / \mathrm{TA}$ & سود انباشته به كل دارايى & 1 \\
\hline$\% 1 \cdot 11$ & .1 .90 &.$/ \cdot 11$ & $\cdot / 11 \mathrm{~V}$ & $\mathrm{~S} / \mathrm{TA}$ & فروش به كل دارايى & r \\
\hline$\% 110$ & $\cdot / \mathrm{VV}$ & $\cdot / 210$ & •/AYr & EBIT/TA & EBIT & r \\
\hline$\% \cdot v \cdot r$ & $.1 .9 \mathrm{~V}$ & $-\cdot / \cdot T t$ & $\cdot / 109$ & EBIT/TS & EBIT به فروش كل EBIT & r \\
\hline$\% \cdot \cdot V$ & $\cdot / 1 V 9$ &.$/ 114$ & $\cdot / T M V$ & GP/TS & سود ناخالص به فروش كل & $\Delta$ \\
\hline$\% v$ & $.199 \mathrm{~V}$ & $\cdot / 1 \cdot 9$ & $\cdot / 091$ & $\mathrm{TD} / \mathrm{TA}$ & كل بدهى به كل دارايى & 9 \\
\hline 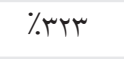 & $\cdot / 9 Y \Lambda$ & $\cdot /$ T99 & $\cdot / 900$ & $\mathrm{TE} / \mathrm{TD}$ & كل حقوق صاحبان سهام به كل بدهى & v \\
\hline$\% 1 \cdot+$ & $\cdot / \wedge \Delta Q$ & $\cdot / \Lambda F Y$ & $\cdot / A V A$ & CUL/TL & بدهى هاى جارى به كل بدهى ها & $\wedge$ \\
\hline$\% \Delta \wedge r$ & $\cdot / \cdot V \Delta$ & $\cdot / \cdot T r$ & $\cdot / T Y V$ & $\mathrm{WC} / \mathrm{TA}$ & سرمايه در گردش به كل دارايىها & 9 \\
\hline$\% 1149$ & $1 / T \wedge$ & $1 / \cdot \wedge k$ & $I / F V Y$ & CUR & نسبت جارى & 1. \\
\hline$\%$ iv. & $\cdot / v+4$ & $\cdot / \Delta Q 1$ & $\cdot / 9 r v$ & QUR & نسبت آنى & 11 \\
\hline$\% r v r$ &.$/ 119$ &.$/ .94$ & $\cdot / I V$ & CAR & نسبت وجه نقد & ir \\
\hline$\% 9 r$ & $-\cdot / \cdot+4$ &.$- / 1149$ & $\cdot / 1 Y \Delta$ & NIM & حاشيه سود خالص & 1 \\
\hline$\%$ TYQ & .1 .99 &.$- / .94$ &.$/ \pi r$. & ROE & بازده حقوق صاحبان سهام & 14 \\
\hline
\end{tabular}


ادامه جدول †: اختلاف ميانكين دادههاى شر كتهاى سالم و ورشكسته

\begin{tabular}{|c|c|c|c|c|c|c|}
\hline قدرمطلق & ميانكين & شر كت ورشين & شر كتهانين & اختصارى & متغيرها (نسبت ها) & 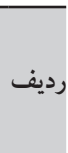 \\
\hline$\%$ & Y/AMT & $9 / 019$ & r/TGV & TA/TSE & نسبت حقوق صاحبان سهام به داريى كل & 10 \\
\hline$\%$ Fr & MI/LQF & $-19 / 0 \cdot 0$ & $V V / q K V$ & DuP & نسبت دويونت & 19 \\
\hline$\% \uparrow \wedge$ & •/.ro & $-\cdot \cdot \cdot 11$ & $\cdot / \bullet \wedge V$ & ROA & بازده دارايىها (ROA) & IV \\
\hline$\% 19$ & $-\cdot / 4 \& 4$ & $-1 / 19$. & $\cdot \pi r$. & RWC & بازده سرمايه در گردش & $1 \wedge$ \\
\hline$\%$ & $-\cdot / T T V$ & $-1 / T \wedge \Delta$ & $\cdot / N \mid r$ & RFA & بازده دارايى ثابت & 19 \\
\hline$\% 91$ & $\cdot / 9 V T$ & $\cdot / V \cdot \Delta$ & .1949 & CUA & نسبت دارايىهاى جارى & $r \cdot$ \\
\hline$\% \uparrow v$ & $r \cdot 9 / 9$ & Grt & $199 / 4$ & MIP & دوره موجودى كالاو مواد & r) \\
\hline$\% 11 r$ & rri & $r \cdot \Lambda$ & rme & $\mathrm{RCP}$ & دوره وصول مطالبات & $r r$ \\
\hline$\% \cdot \cdot q$ & $\cdot / N{ }_{1}$ & $-\cdot \pi \mu V$ & l/9Ar & IN/WC & نسبت كالا به سرمايه در گردش & $r$ \\
\hline$\% \wedge r$ & $\cdot / \cdot v \cdot$ & $\cdot / \cdot v 9$ & .1 .94 & FAT & كردش دارايىهاى ثابت & ry \\
\hline
\end{tabular}

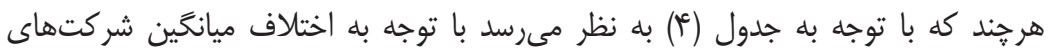
سالم و ورشكسته، امكان شناسايى عوامل موثرتر وجود دارد، ولى نتايج يروهش نشان مى مدهد

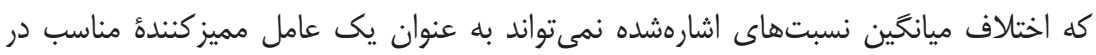
شناسايى عوامل موثرتر مفيد واقع شود. با اين حال و به دليل ايجاد تصويرى كلى از سازوكار اثر اثران

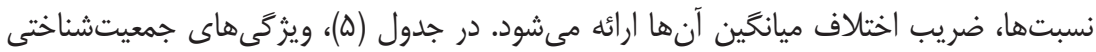

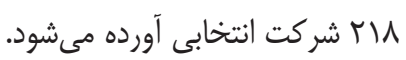

\section{جدول ه: ويز كى هاى جمعيتشناختى شر كتهاى نمونه}

\begin{tabular}{|c|c|c|c|c|}
\hline 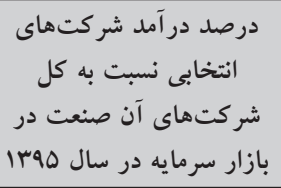 & شركت مجموع حجم درآ آمد انتخابى در & شر كت هاى & صنعت & رديف \\
\hline$\%$ & $1 / T \Lambda \cdot / V 90$ & r & انبوهسازى املاكى و مستغلات & 1 \\
\hline$\% \Delta$ & $r / \Delta r \Delta / \cdot q r$ & r & استخراج كانههاى فلزى & r \\
\hline$\%$ & $019 / 111$ & r & كاشى و سراميك & r \\
\hline$\% \Delta V$ & $11 / \cdot \Delta \Lambda / A M \Lambda$ & 9 & قند و شكر & r \\
\hline
\end{tabular}


ادامه جدول ه: ويزگى هاى جمعيتشناختى شر كتهاى نمونه

\begin{tabular}{|c|c|c|c|c|}
\hline 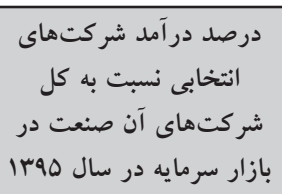 & شركت مجموع حجم در آمد انتخابى در & 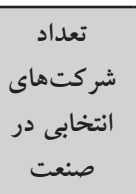 & صنعت & رديف \\
\hline$\% 4$ & $11 /$ KY/4Fq & ir & سيمان آهك گَج & 0 \\
\hline$\% \wedge \wedge$ & $14 / 9 \Delta R / 9 \Lambda$. & 9 & دستخاههاى برقى & 9 \\
\hline$\% r v$ & $0 / 14 \cdot / 1 \cdot 1$ & 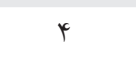 & لاستيك و پِلاستيك & v \\
\hline$\% 1 \wedge$ & $Q / T V Y / T I V$ & IV & غذايى بهجز قند وشكر & $\wedge$ \\
\hline \% & D/LQV/TAK & 1. & محصولات فلزى & 9 \\
\hline$\% \Delta \Delta$ & $1 \cdot / 94 \cdot / 19$. & $r \cdot$ & ماشين آلات و تجهيزات & 1. \\
\hline$\%$. & Q/TMQ/TVq & 14 & كانى غيرفلزى & 11 \\
\hline$\% \notin \Delta$ & $r \cdot / V q V / \cdot Y Q$ & 19 & 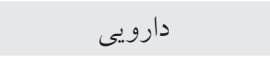 & ir \\
\hline$\% \mu r$ & $\mid K T / F V Y / q \cdot \Lambda$ & IV & شيميايى & ir \\
\hline$\%$ & qMT/Irq & IV & منسوجات & 14 \\
\hline$\% 4$ & $\mid r \Delta / \cdots / \cdots$ & IV & فلزات اساسى & 10 \\
\hline$\% \mu r$ & $109 / \cdots / \cdots$ & It & خودرو و قطعات & 19 \\
\hline- & $11 \cdot / 99 \cdot / 0 \cdot r$ & TV & ساير صنايع** & IV \\
\hline
\end{tabular}

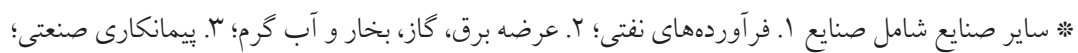

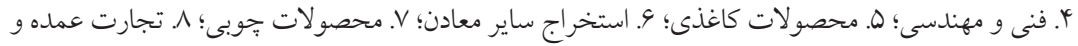

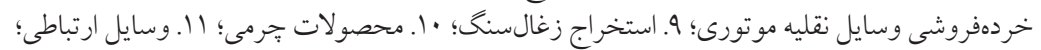

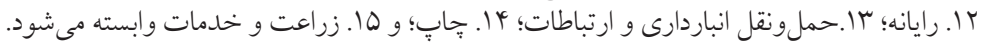

\section{نتايج تجربى}

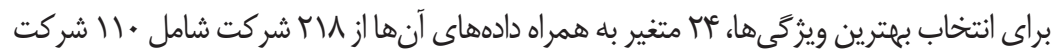
سالم (با جهار سال فعاليت متوالى و مشمول ورشكسته نشدن)، و + ( شركت ورشكسته (با سه سال فعاليت متوالى و مشمول ورشكسته نشدن و ورشكستخى در سال جيهارم) وارد نرمافزار متلب مى شوند و الخوريتم كلونى مورجگان به انتخاب بهترين ويثزى ها از ميان عاب متغير مىيردازد. ينج متغير شامل EBIT به فروش كل، كل حقوق صاحبان سهام به كل بدهى، نسبت جارى، نسبت وجه نقد، و نسبت حقوق صاحبان

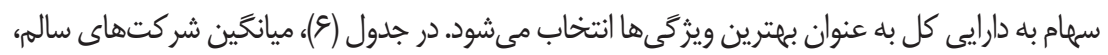
ورشكسته، و كل هر يك از شاخصهاى انتخابى براى سال هاى tt، t-2، t-1، t-3 آورده مىشود. 
جدول 9: ميانكين شر كتهاى سالم، ورشكسته، و كل هر يك از شاخصهاى انتخابى

\begin{tabular}{|c|c|c|c|c|c|c|c|c|c|c|c|c|}
\hline \multicolumn{4}{|c|}{ ميانخين كل } & \multicolumn{4}{|c|}{ ميانخين شركتهاى ورشكسته } & \multicolumn{4}{|c|}{ ميانخين شركتهاى سالم } & \\
\hline $\mathbf{t}$ & $t-1$ & $t-2$ & & - & & 40 & 18 & 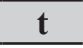 & & 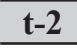 & $t-3$ & \\
\hline ra & & & & & & & $Y Y / N F Q$ & & & & $9 / 9 \vee \Delta$ & \\
\hline & & & & & & & & & & & & \\
\hline & 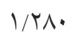 & & & & & & & & & & & \\
\hline & & & & & & & & & & & $. / 11 /$ & \\
\hline & 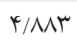 & & & & & & & & & & & \\
\hline
\end{tabular}

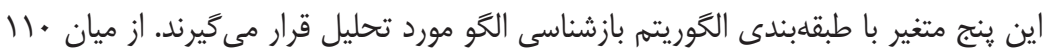

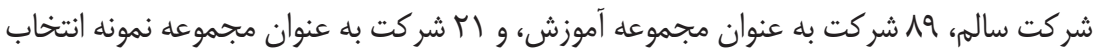

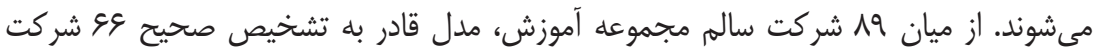
است و سז شر كت باقى مانده سالم در دسته شركتهاى ورشكسته دستهبندى مىشوند. در واقع، در

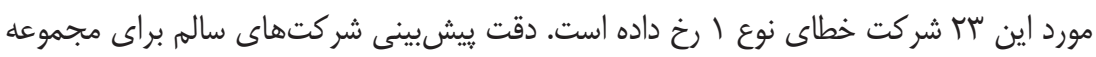

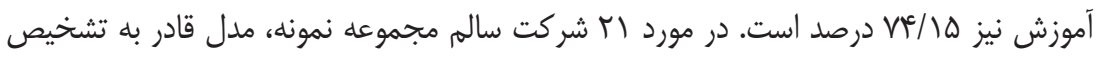
صحيح ها عدد از آنهاست و و شركت سالم نيز در دسته شركتهاى ورشكسته جاى مى گيرند.

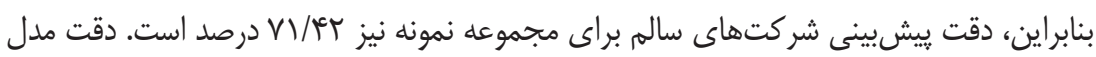
در برآورد شر كتهاى سالم (مجموعه آموزش و مجموعه نمونه) سع/سل درصد است. از ميان 1+1 شركت ورشكسته هم شركت به عنوان مجموعه آموزش و سז شركت به عنوان مجموعه نمونه انتخاب مىشوند. از ميان هم شركت ورشكسته مجموعه آموزش، مدل قادر به تشخيص

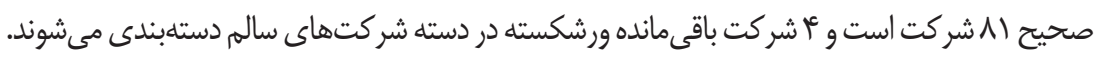
در واقع، در مورد اين أ شركت خطاى نوع r رخ داده است. دقت ييشبينى شركتهاى ورشكسته براى مجموعه آموزش نيز وج/هو درصد است. در مورد سץ شركت ورشكسته مجموعه نمونه، مدل قادر

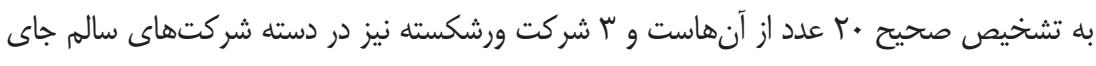
مى گيرند. بنابراين، دقت يِيشبينى شركتهاى ورشكسته براى مجموعه نمونه نيز هو/عN درصد است.

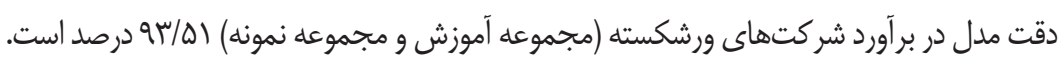

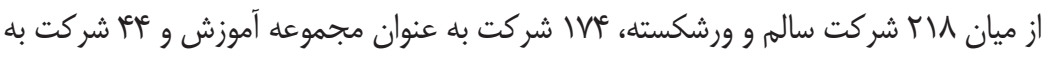

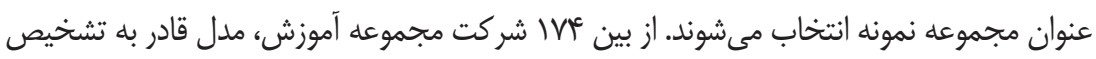

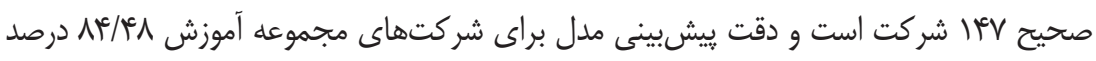


است. از ميان عَّ شركت سالم و ورشكسته مجموعه نمونه، مدل قادر به تشخيص صحيح هـ شركت

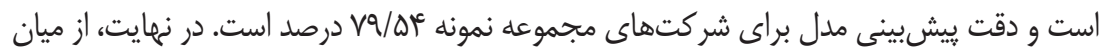

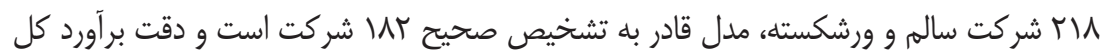

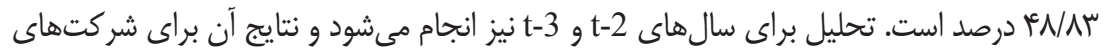

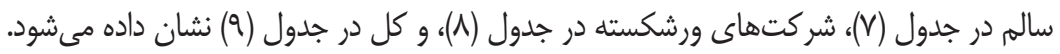

\begin{tabular}{|c|c|c|c|c|c|c|c|}
\hline \multicolumn{2}{|c|}{ 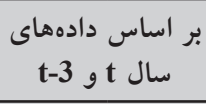 } & \multicolumn{2}{|c|}{ بر اساس د و و t-2 toاى } & \multicolumn{2}{|c|}{ بر اساس t و دادههاى } & & \multirow[t]{2}{*}{ نوع داده } \\
\hline درصد & تعداد & درصد & تعداد & درصد & تعداد & & \\
\hline & 91 & & 19 & & 19 & & \\
\hline$\% 9 \cdot / 4 t$ & $\Delta Q$ & $\% \Delta \Delta / \cdot 9$ & $4 q$ & $\% v 4 / 19$ & 94 & بر آورد صحيح & 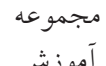 \\
\hline \multirow[t]{2}{*}{$\%$ \%/Dq } & rq & $\% 4 y / 94$ & 4. & $\%$ YQ/Aץ & r & بر آورد خطا (خطاى نوع 1) & \\
\hline & 19 & & rI & & YI & & \multirow{3}{*}{ مجموعه } \\
\hline$\%$ \% /AY & v & $\% \Delta V / 1 Y$ & ir & $\%$ Vi/kr & 10 & بر آورد صحيح & \\
\hline$\% 9 r / 19$ & ir & \%YY/AG & 9 & $\%$ YN/QV & 4 & بر آورد خطا (خطاى نوع 1) & \\
\hline
\end{tabular}

جدول ^: دقت بيشينى ريسك اعتبارى شركتهاى ورشكسته سال t با استفاده از دادههاى سال هاى قبل ش

\begin{tabular}{|c|c|c|c|c|c|c|c|}
\hline \multicolumn{2}{|c|}{ بال t و t-3 اسدهاى } & \multicolumn{2}{|c|}{ بر اساس د و و t-2 ادهاى } & \multicolumn{2}{|c|}{ سال t و اساس دادههاى } & & \multirow{2}{*}{ توع داده } \\
\hline \multirow[t]{2}{*}{ درصد } & تعداد & درصد & تعداد & درصد & تعداد & & \\
\hline & N & & $\wedge \otimes$ & & $\wedge \Delta$ & & \multirow{3}{*}{ آموزش مجموعه } \\
\hline$\% q \cdot / 4 q$ & $V Q$ & $\% 9 r / 94$ & va & $\% 90 / r 9$ & $\wedge 1$ & برآورد صحيح & \\
\hline \multirow[t]{2}{*}{$\% q / 94$} & $\wedge$ & $\% v / \cdot 4$ & 4 & $\% 4 / v 1$ & r & برآورد خطا (خطاى نوع r) & \\
\hline & rQ & & r & & r & & \multirow{3}{*}{ نمونه } \\
\hline$\% \wedge r$ & r) & $\% 91 / r$ & YI & $\% \wedge 9 / 99$ & $r$. & برآورد صحيح & \\
\hline$\% 19$ & r & $\% \wedge / v$ & r & $\% \mu \%+4$ & r & برآورد خطا (خطاى نوع r) & \\
\hline
\end{tabular}


جدول 9: دقت بيشيينى ريسك اعتبارى كل، سال t با استفاده از دادههاى سالهاى قبل

\begin{tabular}{|c|c|c|c|c|c|c|c|}
\hline \multicolumn{6}{|c|}{ 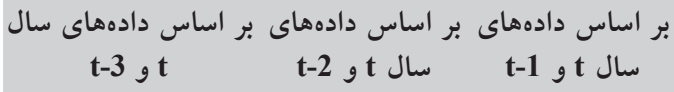 } & & \multirow[t]{2}{*}{ نوع داده } \\
\hline درصد & تعداد & درصد & تعداد & درصد & تعداد & & \\
\hline & IVt & & IVY & & IVt & & \\
\hline$\% v Y / v 1$ & $1 r$. & $\% V T / D Q$ & ITA & $\% \wedge \uparrow / 4 \wedge$ & $14 \mathrm{~V}$ & بر آورد صحيح & مجموعه آموزش \\
\hline \multirow[t]{2}{*}{$\%$ \% / rq } & ky & $\%$ TS/4r & 49 & $\% 1 Q / \Delta T$ & TV & بر آورد اشتباه & \\
\hline & kq & & kt & & ky & & \\
\hline \% & rA & $\%$ vo & r & $\% \vee \vee / \Delta D$ & ro & برآورد صحيح & مجموعه نمونه \\
\hline \multirow[t]{2}{*}{ \% } & 19 & $\%$ YQ & 11 & $\%$ \% $/ 4 \Delta$ & 9 & برآورد اشتباه & \\
\hline & riA & & TIN & & YIN & & \\
\hline$\% V Y / Y \wedge$ & 101 & $\% / N / \wedge D$ & 191 & $\% \wedge r / 4 q$ & MT & برآورد صحيح & كل \\
\hline$\%$ YV/DT & 9. & $\% r 4 / 10$ & $\Delta V$ & $\% 19 / 01$ & ma & برآورد اشتباه & \\
\hline
\end{tabular}

جدول (•(1)، بررسى تطبيقى نتايج يثوهش را از نظر دقت ييشبينى با ساير يثوهشها نشان

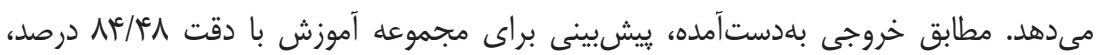
براى مجموعه نمونه با دقت VQ/DQ درصد، و در مجموع با دقت وع/

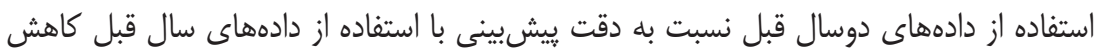

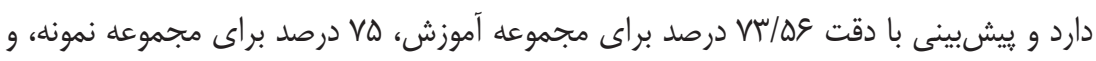

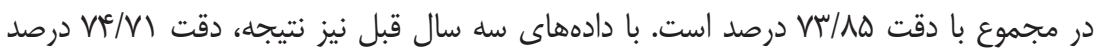

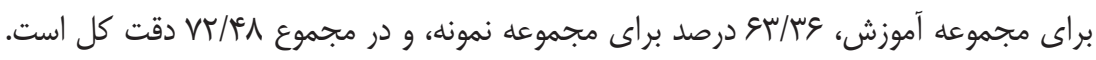
دقت خروجى حاصل از ييشبينى وضعيت اعتبارى شركت با استفاده از دادههاى هر سه سال نشان

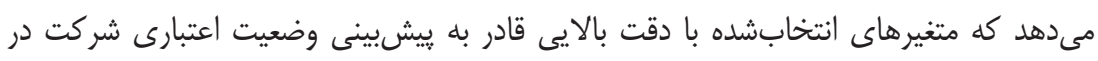

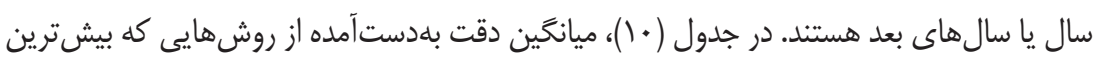

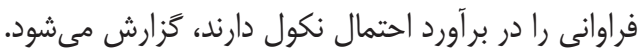


جدول • ا: بررسى تطبيقى نتايج بثوهش حاضر با بثروهشهاى بيشين

\begin{tabular}{|c|c|c|c|c|c|c|c|}
\hline \multicolumn{7}{|c|}{ ميانخين درصدها } & \multirow[t]{2}{*}{ عنوان } \\
\hline k نزديك ترين & تحليل مميزى & تصميم & رجرسيون & ماشين بردار & عصبى & جزؤش حاضر & \\
\hline q & $\wedge$ & $\wedge$ & 14 & 19 & $r$ & & تعداد \\
\hline $99 / 19$ & $v \cdot / q$ & $V T / 90$ & $V Q / \cdot q$ & $V \wedge / 19$ & $\mathrm{VV} / 99$ & $\Lambda r / 4 q$ & درصد \\
\hline
\end{tabular}

برخى از روشها قادر هستند با درصد دقت بلنسبت بالايى وضعيت اعتبارى شركت را

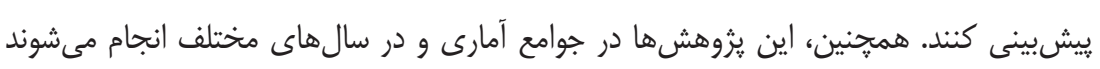
و منطقى است كه هرجه عوامل محيط كلان شركت و وضعيت مالى و اقتصادى جامعه بيشتر की دجار نوسانهاى بزرگ شوند، احتمال برآورد صحيح نيز كاهش يابد. همانطور كه در جدول (·)

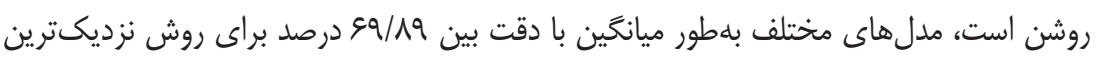
k همسايكى تا VN/19 براى روش ماشين بردار قادر به ييشبينى وضعيت اعتبارى شركت هستند.

\section{بحث و نتيجه Fيرى}

هدف از انجام يزوهش حاضر شناسايى مهمترين متغيرهاى موثر در ريسك اعتبارى و

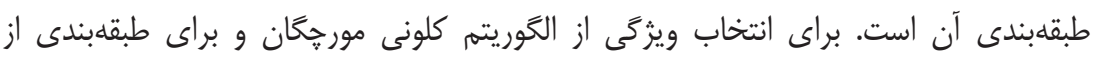

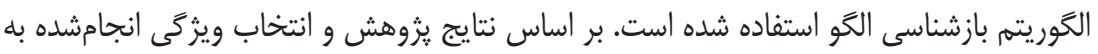
وسيله الخوريته كلونى مورجًان، ينج متغير شامل سود قبل از كسر بهره و ماليات به فروش كل، كل حقوق صاحبان سهام به كل بدهى، نسبت جارى، نسبت وجه نقد، و نسبت حقوق صاحبان

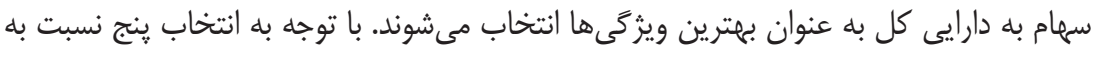
عنوان موثرترين عوامل در ييشبينى ورشكستخى و وضعيت اعتبارى شركتها، اقلام موجود در ترازنامه و صورت سود و زيان شركت شامل سود قبل از بهره و ماليات، كل حقوق صاحبان سهام،

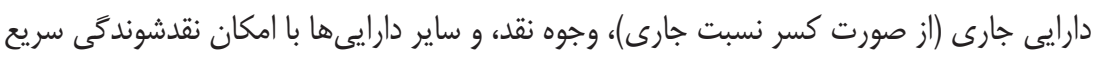
(از صورت كسر نسبت وجه نقد) از اهميت ويثماى برخوردار است و با توجه به اين كه اقلام به صورت نسبت در معادله وضعيت اعتبارى قرار مى گيرند، ميزان قابلقبول هر يك از آنها با توجه

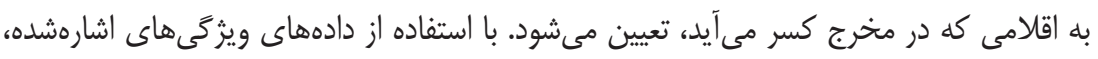
طبقلبندى شركتهاى نمونه انجام مىشود. مطابق نتايج، امكان ييشبينى احتمال ورشكستخى مئى 
شر كتها با دقت بالايى براى مجموعه آموزش، مجموعه نمونه، و كل وجود دارد.

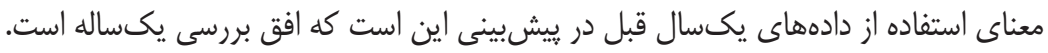

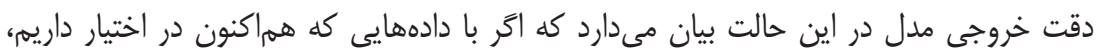

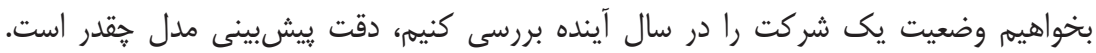

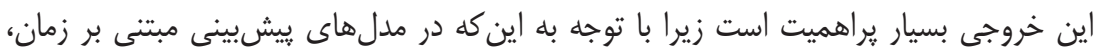

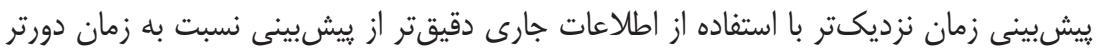

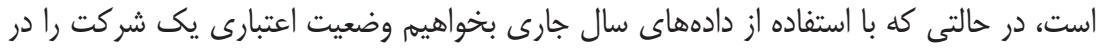
سال آينده ييشبينى كنيه، دقت مدل نسبت به حالتى كه مىخواهيم با همين اطلاعات، وضعيت

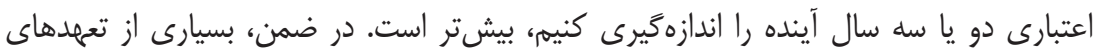

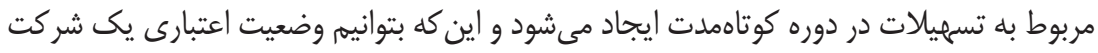

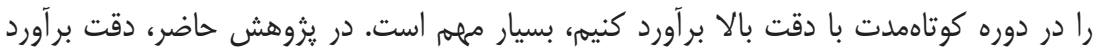

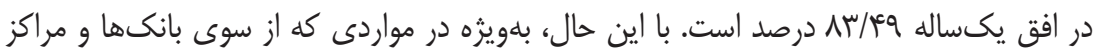
مالى و اعتبارى تسهيلات بلندمدت به شركتها اعطا مى شود، هم وضعيت اعتبارى كوتاهمدت و و

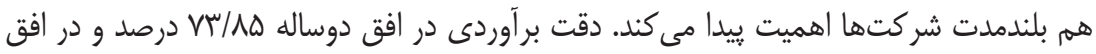

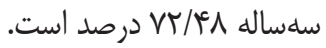
در اين يزوهش، هر دو عمليات انتخاب ويثگى و طبقهبندى با استفاده از روشهاى يادَيرى

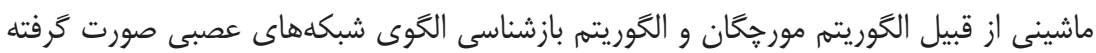

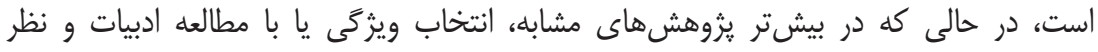

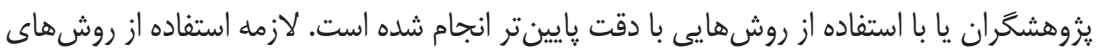
يادگيرى ماشينى، مانند دو روش اشارهشده، وجود حجم مناسبى از داده است كه اين دادهها براى

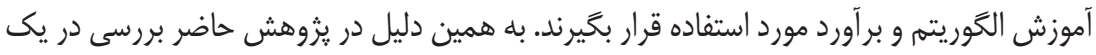

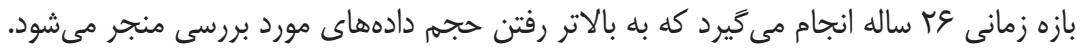

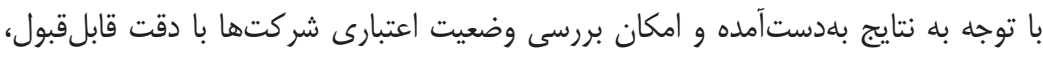

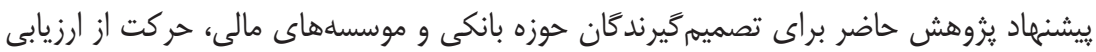
سنتى وضعيت اعتبارى به ارزيابى بر اساس مدلهاى نوين و مبتنى بر يادكّيرى ماشينى است تاكي

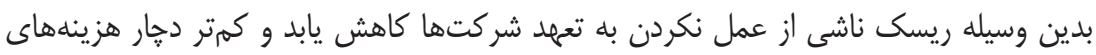

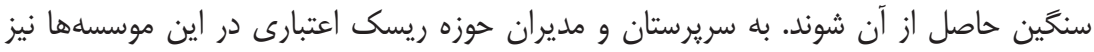

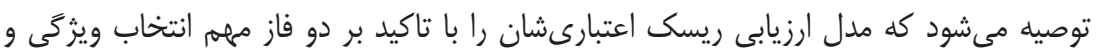


طبقهبندى بر اساس روشهاى دقيق طراحى كنند و از بروز خطاى مبتنى بر قضاوت در تعيين شاخصهاى ريسك اعتبارى خوددارى كنند.

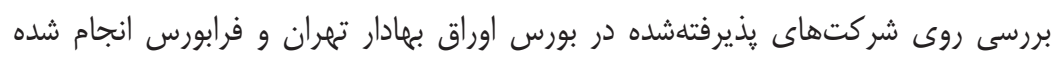

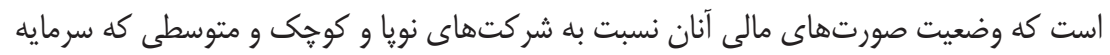

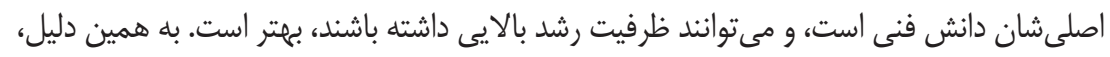

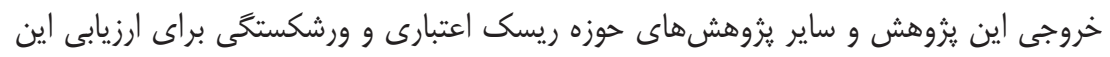

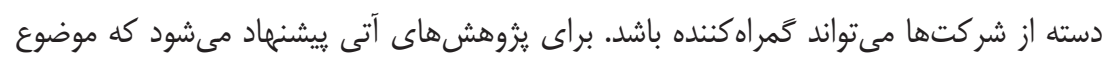

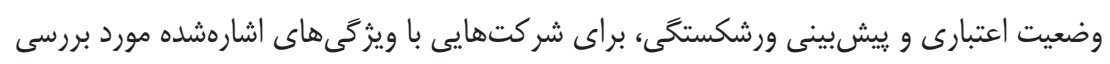

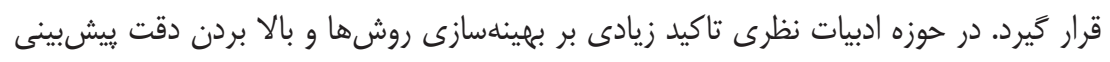

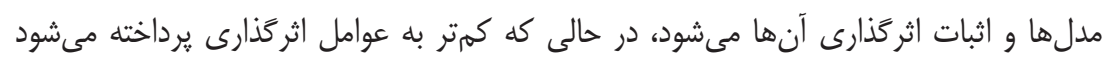

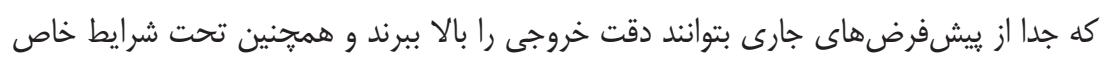

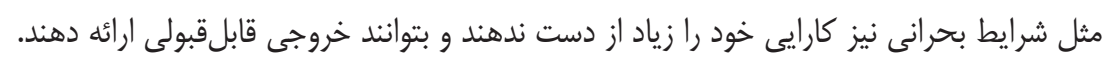

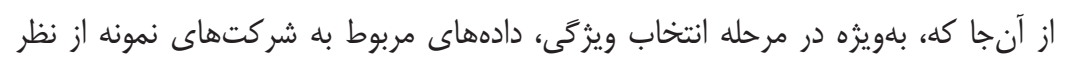

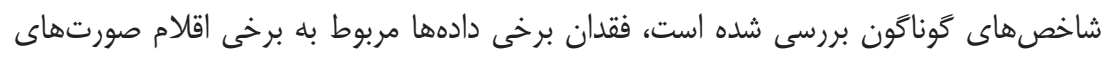

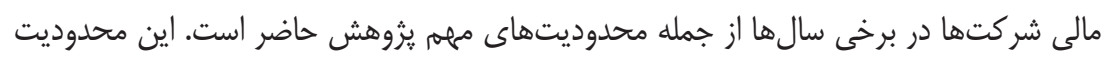

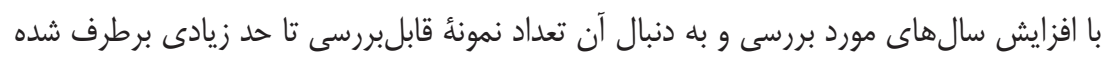

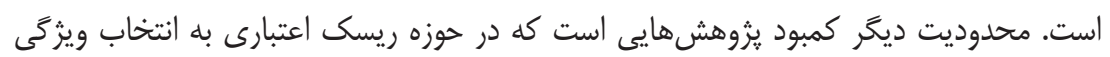
يرداخته باشند.

\section{منابع}

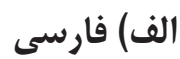

خليلى، جواد، و علىنزاد، عليرضا (هوج"). ارزيابى عملكرد واحدهاى تصميمَيرينده با استفاده از تحليل

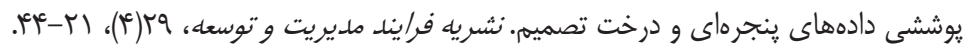

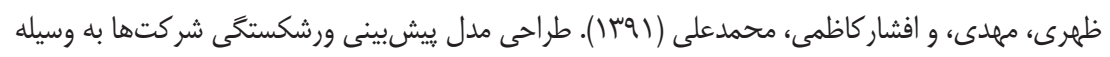

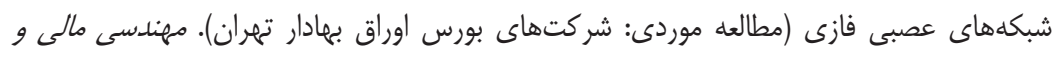

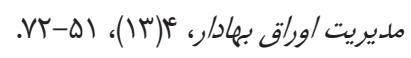

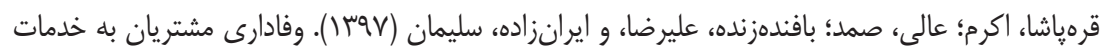

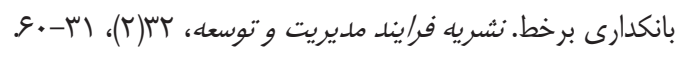




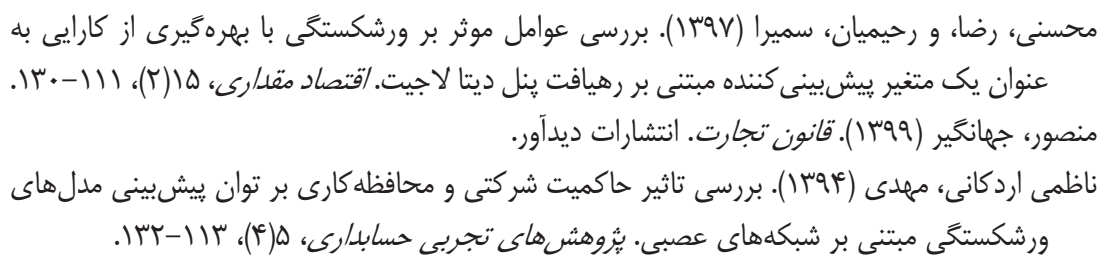

Alaka, H. A., Oyedele, L. O., Owolabi, H. A., Kumar, V., Ajayi, S. O., Akinade, O. O., \& Bilal, M. (2018). Systematic Review of Bankruptcy Prediction Models: Towards a Framework for Tool Selection. Expert Systems with Applications, 94(1), 164-184.

Antunes, F., Ribeiro, B., \& Pereira, F. (2017). Probabilistic Modeling and Visualization for Bankruptcy Prediction. Applied Soft Computing, 60(1), 831-843.

Arieshanti, I., Purwananto, Y., Ramadhani, A., Nuha, M. U., \& Ulinnuha, N. (2013). Comparative Study of Bankruptcy Prediction Models. Telkomnika, 11(3), 591-596.

Barboza, F., Kimura, H., \& Altman, E. (2017). Machine Learning Models and Bankruptcy Prediction. Expert Systems with Applications, 83(1), 405-417.

Berg, D. (2007). Bankruptcy Prediction by Generalized Additive Models. Applied Stochastic Models in Business and Industry, 23(2), 129-143.

Boratyńska, K., \& Grzegorzewska, E. (2018). Bankruptcy Prediction in the Agribusiness Sector: Lessons from Quantitative and Qualitative Approaches. Journal of Business Research, 89(1), 175-181.

Chen, H.-L., Yang, B., Wang, G., Liu, J., Xu, X., Wang, S.-J., \& Liu, D.-Y. (2011). A Novel Bankruptcy Prediction Model Based on an Adaptive Fuzzy k-Nearest Neighbor Method. Knowledge-Based Systems, 24(8), 1348-1359.

Chen, Z., Chen, W., \& Shi, Y. (2020). Ensemble Learning with Label Proportions for Bankruptcy Prediction. Expert Systems with Applications, 146.

Cho, S., Hong, H., \& Ha, B. C. (2010). A Hybrid Approach Based on the Combination of Variable Selection Using Decision Trees and Case-Based Reasoning Using the Mahalanobis Distance: For Bankruptcy Prediction. Expert Systems with Applications, 37(4), 3482-3488.

Chou, C.-H., Hsieh, S.-C., \& Qiu, C.-J. (2017). Hybrid Genetic Algorithm and Fuzzy Clustering for Bankruptcy Prediction. Applied Soft Computing, 56(1), 298-316.

De Andrés, J., Landajo, M., \& Lorca, P. (2012). Bankruptcy Prediction 
Models Based on Multinorm Analysis: An Alternative to Accounting Ratios. Knowledge-Based Systems, 30(1), 67-77.

Divsalar, M., Firouzabadi, A. K., Sadeghi, M., Behrooz, A. H., \& Alavi, A. H. (2011). Towards the Prediction of Business Failure via Computational Intelligence Techniques. Expert Systems, 28(3), 209-226.

Djebali, N., \& Zaghdoudi, K. (2020). Threshold Effects of Liquidity Risk and Credit Risk on Bank Stability in the MENA Region. Journal of Policy Modeling. In press

Du Jardin, P. (2015). Bankruptcy Prediction Using Terminal Failure Processes. European Journal of Operational Research, 242(1), 286-303.

Du Jardin, P. (2016). A Two-Stage Classification Technique for Bankruptcy Prediction. European Journal of Operational Research, 254(1), 236-252.

Du Jardin, P., \& Séverin, E. (2012). Forecasting Financial Failure Using a Kohonen Map: A Comparative Study to Improve Model Stability over Time. European Journal of Operational Research, 221(2), 378-396.

Estévez, P. G., \& Carballo, A. (2015). Qualitative Judgement in Public Credit Ratings: A Proposed Supporting Approach Using Self-Organising Maps (SOMs). Cuadernos de Economía, 38(108), 181-190.

Fanelli, V., \& Maddalena, L. (2020). A Nonlinear Dynamic Model for Credit Risk Contagion. Mathematics and Computers in Simulation, 174(1), 45-58.

Fernandes, G. B., \& Artes, R. (2016). Spatial Dependence in Credit Risk and Its Improvement in Credit Scoring. European Journal of Operational Research, 249(2), 517-524.

Gepp, A., \& Kumar, K. (2008). The Role of Survival Analysis in Financial Distress Prediction. International Research Journal of Finance and Economics, 16(16), 13-34.

García, V., Marqués, A. I., \& Sánchez, J. S. (2019). Exploring the Synergetic Effects of Sample Types on the Performance of Ensembles for Credit Risk and Corporate Bankruptcy Prediction. Information Fusion, 47(1), 88-101.

Gordini, N. (2014). A Genetic Algorithm Approach for SMEs Bankruptcy Prediction: Empirical Evidence from Italy. Expert Systems with Applications, 41(14), 6433-6445.

Grunert, J., Norden, L., \& Weber, M. (2005). The Role of Non-Financial Factors in Internal Credit Ratings. Journal of Banking \& Finance, 29(2), 509-531.

He, Y., Xu, Z., \& Gu, J. (2016). An Approach to Group Decision Making with Hesitant Information and Its Application in Credit Risk Evaluation of Enterprises. Applied Soft Computing, 43(1), 159-169.

Huang, X., Liu, X., \& Ren, Y. (2018). Enterprise Credit Risk Evaluation Based 
on Neural Network Algorithm. Cognitive Systems Research, 52(1), 317-324. Jabeur, S. B. (2017). Bankruptcy Prediction Using Partial Least Squares Logistic Regression. Journal of Retailing and Consumer Services, 36(1), 197-202.

Jeong, C., Min, J. H., \& Kim, M. S. (2012). A Tuning Method for the Architecture of Neural Network Models Incorporating GAM and GA As Applied To Bankruptcy Prediction. Expert Systems with Applications, 39(3), 3650-3658.

Kim, M. J., \& Kang, D. K. (2010). Ensemble with Neural Networks for

Bankruptcy Prediction. Expert Systems with Applications, 37(4), 3373-3379. Kim, H.-J., Jo, N.-O., \& Shin, K.-S. (2016). Optimization of Cluster-Based Evolutionary Undersampling for the Artificial Neural Networks in Corporate Bankruptcy Prediction. Expert Systems with Applications, 59(1), 226-234.

Liang, D., Lu, C.-C., Tsai, C.-F., \& Shih, G.-A. (2016). Financial Ratios and Corporate Governance Indicators in Bankruptcy Prediction: A Comprehensive Study. European Journal of Operational Research, 252(2), 561-572.

Liu, C., Xie, J., Zhao, Q., Xie, Q., \& Liu, C. (2019). Novel Evolutionary Multi-Objective Soft Subspace Clustering Algorithm for Credit Risk Assessment. Expert Systems with Applications, 138.

Lyandres, E., \& Zhdanov, A. (2013). Investment Opportunities and Bankruptcy Prediction. Journal of Financial Markets, 16(3), 439-476.

Mai, F., Tian, S., Lee, C., \& Ma, L. (2019). Deep Learning Models for Bankruptcy Prediction Using Textual Disclosures. European Journal of Operational Research, 274(2), 743-758.

Nam, J. H., \& Jinn, T. (2000). Bankruptcy Prediction: Evidence from Korean Listed Companies During the IMF Crisis. Journal of International Financial Management \& Accounting, 11(3), 178-197.

Piramuthu, S. (1999). Financial Credit-Risk Evaluation with Neural and Neurofuzzy Systems. European Journal of Operational Research, 112(2), 310-321.

Pompe, P. P., \& Bilderbeek, J. (2005). Bankruptcy Prediction: The Influence of the Year Prior to Failure Selected for Model Building and the Effects in a Period of Economic Decline. Intelligent Systems in Accounting, Finance \& Management: International Journal, 13(2), 95-112.

Psillaki, M., Tsolas, I. E., \& Margaritis, D. (2010). Evaluation of Credit Risk Based on Firm Performance. European Journal of Operational Research, 201(3), 873-881.

Qu, Y., Quan, P., Lei, M., \& Shi, Y. (2019). Review of Bankruptcy 
PredictionUsing Machine Learning and Deep Learning Techniques. Procedia Computer Science, 162(1), 895-899.

Shi, Y., \& Li, X. (2019). A Bibliometric Study on Intelligent Techniques of Bankruptcy Prediction for Corporate Firms. Heliyon, 5(12), 1-12.

Shie, F. S., Chen, M. Y., \& Liu, Y. S. (2012). Prediction of Corporate Financial Distress: An Application of the America Banking Industry. Neural Computing and Applications, 21(7), 1687-1696.

Sironi, A., \& Resti, A. (2007). Risk Management and Shareholders' Value in Banking: From Risk Measurement Models to Capital Allocation Policies (Vol. 417): John Wiley \& Sons.

Soares, J. O., Pina, J., Ribeiro, M., \& Lopes, M. C. (2011). Quantitative VS. Qualitative Criteria for Credit Risk Assessment. Frontiers in Finance and Economics, 8(1), 69-87.

Son, H., Hyun, C., Phan, D., \& Hwang, H. J. (2019). Data Analytic Approach for Bankruptcy Prediction. Expert Systems with Applications, 138.

Sousa, M. R., Gama, J., \& Brandão, E. (2016). A New Dynamic Modeling Framework for Credit Risk Assessment. Expert Systems with Applications, 45(1), 341-351.

Tobback, E., Bellotti, T., Moeyersoms, J., Stankova, M., \& Martens, D. (2017). Bankruptcy Prediction for SMEs Using Relational Data. Decision Support Systems, 102(1), 69-81.

Tsai, C. F., \& Hsu, Y. F. (2013). A Meta-Learning Framework for Bankruptcy Prediction. Journal of Forecasting, 32(2), 167-179.

Tsai, C.-F., Hsu, Y.-F., \& Yen, D. C. (2014). A Comparative Study of Classifier Ensembles for Bankruptcy Prediction. Applied Soft Computing, 24(1), 977-984.

Veganzones, D., \& Séverin, E. (2018). An Investigation of Bankruptcy Prediction in Imbalanced Datasets. Decision Support Systems, 112(1), 111-124.

Virág, M., \& Nyitrai, T. (2014). Is There a Trade-Off Between the Predictive Power and the Interpretability of Bankruptcy Models? The Case of the First Hungarian Bankruptcy Prediction Model. Acta Oeconomica, 64(4), 419-440.

Volkov, A., Benoit, D. F., \& Van den Poel, D. (2017). Incorporating Sequential Information in Bankruptcy Prediction with Predictors Based on Markov for Discrimination. Decision Support Systems, 98(1), 59-68.

Wang, M., Chen, H., Li, H., Cai, Z., Zhao, X., Tong, C., ... Xu, X. (2017). Grey Wolf Optimization Evolving Kernel Extreme Learning Machine: Application to Bankruptcy Prediction. Engineering Applications of Artificial Intelligence, 63(1), 54-68.

Xiong, T., Wang, S., Mayers, A., \& Monga, E. (2013). Personal Bankruptcy Prediction by Mining Credit Card Data. Expert Systems with Applications, 
40(2), 665-676.

Yang, Z., You, W., \& Ji, G. (2011). Using Partial Least Squares and Support Vector Machines for Bankruptcy Prediction. Expert Systems with Applications, 38(7), 8336-8342.

Yoon, J. S., \& Kwon, Y. S. (2010). A Practical Approach to Bankruptcy Prediction for Small Businesses: Substituting the Unavailable Financial Data for Credit Card Sales Information. Expert Systems with Applications, 37(5), 3624-3629.

Zhou, L., Lai, K. K., \& Yen, J. (2012). Empirical Models Based on Features Ranking Techniques for Corporate Financial Distress Prediction. Computers \& Mathematics with Applications, 64(8), 2484-2496.

Zhou, L., Lai, K. K., \& Yen, J. (2014). Bankruptcy Prediction Using SVM Models with a New Approach To Combine Features Selection and Parameter Optimisation. International Journal of Systems Science, 45(3), 241-253.

Zięba, M., Tomczak, S. K., \& Tomczak, J. M. (2016). Ensemble Boosted Trees with Synthetic Features Generation in Application to Bankruptcy Prediction. Expert Systems with Applications, 58(1), 93-101.

Zoričák, M., Gnip, P., Drotár, P., \& Gazda, V. (2020). Bankruptcy Prediction for Small-and Medium-Sized Companies Using Severely Imbalanced Datasets. Economic Modelling, 84(1), 165-176. 